\title{
Livy's Witch-hunts
}

A Study of Investigations into Veneficium found in Livy

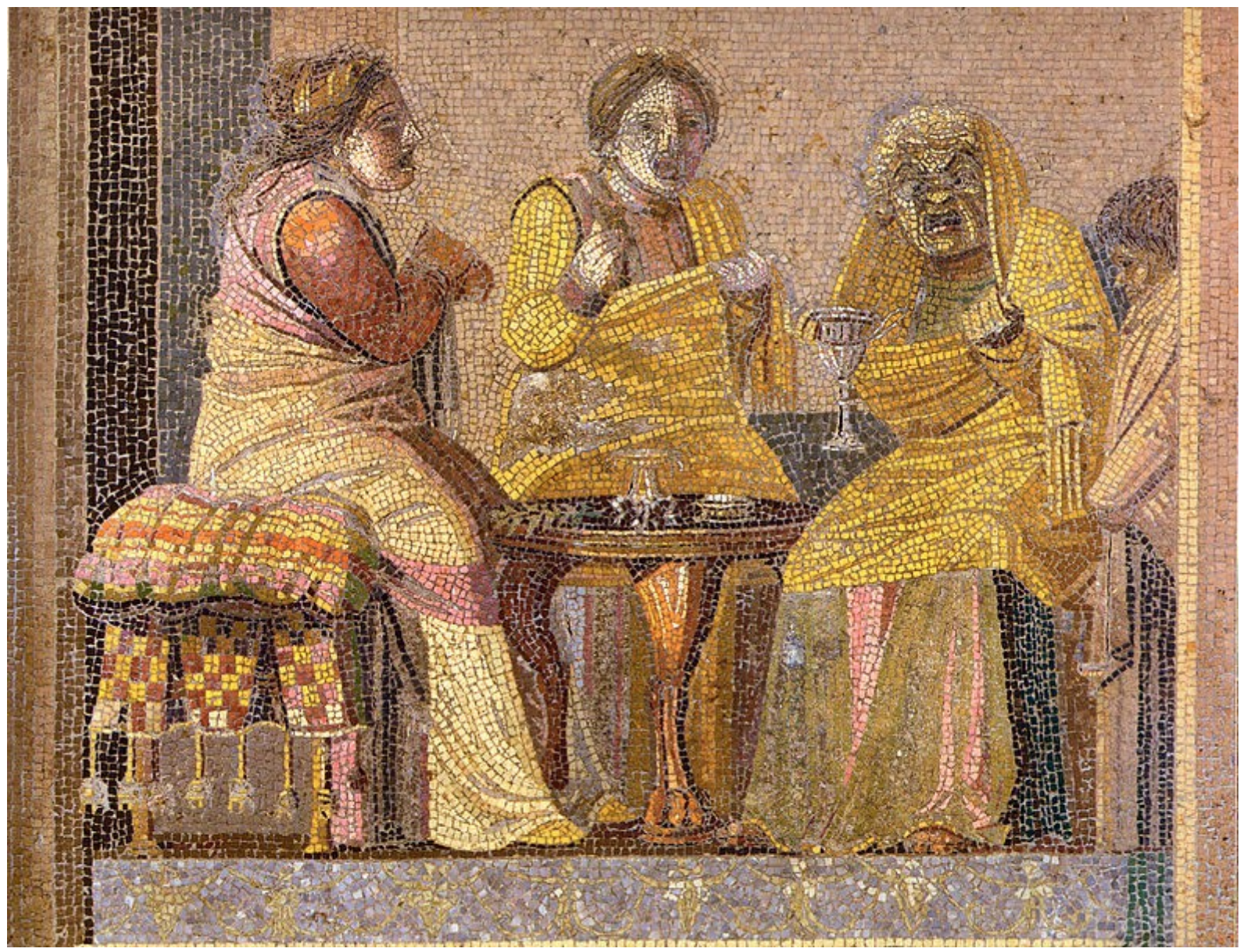

Liam Grandy

Thesis submitted to Victoria University of Wellington in fulfilment of the requirement for the degree of Master of Arts in Classics 
Mosaic depicting a group of four masked characters at a table. Originally believed to depict women acquiring the services of a witch, now it is more commonly believed to be a mosaic copy of a Greek fresco depicted a scene from a lost play by Menander. Found in the Villa of Cicero, held in the Archaeological Museum of Naples. Image from:

https://www.museoarcheologiconapoli.it/en/room-and-sections-of-the-exhibition/mosaics/

Accessed on $29 / 6 / 2018$

Cropped and colour corrected by the author.

Used with the permission of the National Archeolgical Museum of Naples.

"su concessione del Ministero per i Beni e le Attività Culturali - Museo Archeologico

Nzionale de Napoli." 
Contents

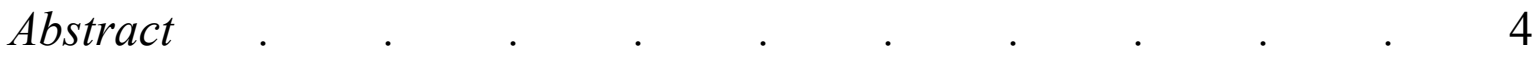

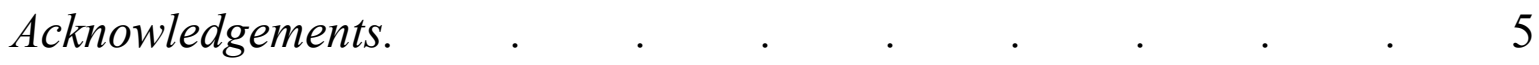

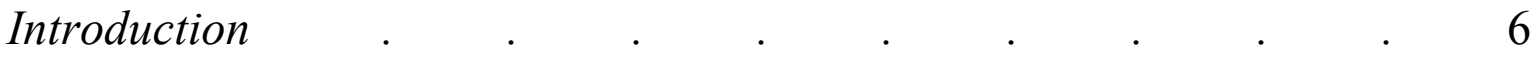

Chapter One: Poison, Potion, or Magic? $\quad . \quad$. $\quad$. $\quad$. $\quad$. 10

Chapter Two: Veneficium in the Quaestiones of Livy _ . 33

Chapter Three: Veneficium Investigations as a Symptom of Social Anxiety 49

Chapter Four: Interdisciplinary Interpretations of Livy's Quaestiones . 61

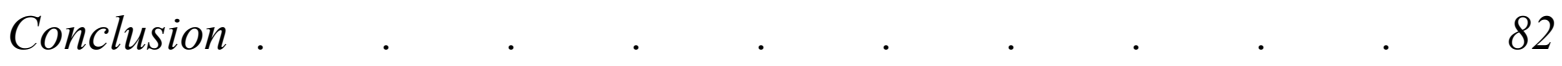

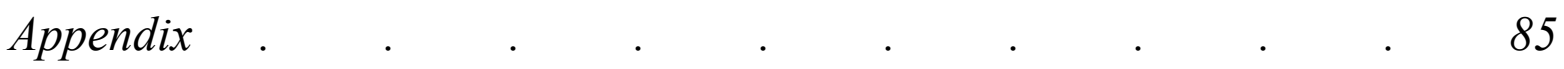

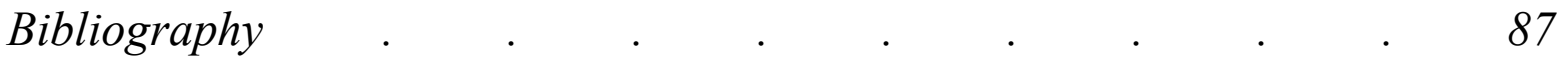




\section{Abstract}

This thesis is an exploration of large scale incidents of veneficium as they are depicted in Livy's Ab Urbe Condita. Livy's earlier books include references to four quaestiones de veneficiis, investigations into poisoning, which resulted in the executions of thousands of people. This study attempts to understand what happened while hypothesising why they occurred.

Veneficium and its associated words have often been declared ambiguous, referring to poisons, potions, and, eventually, magic. However, this interpretation developed significantly later than the events seen in Livy and is anachronistic. This thesis explores this language and so we can understand what veneficium meant during the quaestiones de veneficiis of the fourth and second centuries BC and in Livy's own time, and how it evolved to become magical and thus colour modern scholarships. Using this knowledge, we can review and reconsider Livy's reports to gain a fresh understanding of what actually happened during the quaestiones and how the motifs and themes of these investigations reveal that they were in fact social responses to a period of rapid change to Roman life in the second century BC. This final point is reaffirmed when we engage with interdisciplinary theories from anthropology and sociology. By considering theories and models from these schools we can confidently say that, while venefici were not witches, their persecution was a type of witch-hunt. 


\section{Acknowledgments}

There are a number of people without whom I would not have been able to have undertake and complete this project.

First and foremost, I would like to thank my supervisor, Professor Arthur Pomeroy. His support during this project has been invaluable and his suggestions have encouraged me to produce a better piece of work. Additionally, his film and television recommendations have served as a respite from work. I would also like to thank Dr Simon Perris, Dr James McNamara, and Dr James Kierstead whose advice following a seminar on my thesis opened avenues of thought I had not considered.

Thanks must be given to the Classics Department of Victoria University of Wellington. Having begun my undergraduate studies in 2010, the department has continued to support me with tutor work and encouragement between my undergraduate degree and my master's thesis. The department is a family and I am deeply indebted to ever lecturer, tutor, and school administrator I have had the pleasure of interacting with.

Special thanks should also be given to my office colleagues Stacey Wellington, Tim Smith, Ziming Liu, Alice Fairley, and Melanie Teahan. The comradery that we shared has been incredibly supportive and helped me maintain a degree of sanity during the thesis process.

Finally, I would like to thank my flatmates, friends and family who provided me with love and encouragement during my Masters. I could not have finished this without you. 


\section{Introduction}

According to Livy, between $331 \mathrm{BC}$ and $154 \mathrm{BC}$, over five thousand people were executed on the charge of veneficium during quaestiones, and yet, no extended study of the topic exists. This thesis aims to contribute to the scholarship on this topic.

While there is no scholarly work that solely looks at these trials in Livy, academics have broached these investigations as part of larger works. David Kaufman, in a short study of the history of poison in Rome, matter-of-factly asserts that the quaestiones were investigations of mass poison. ${ }^{1}$ Fritz Graf argues that veneficium was only used in the second century to refer to any sudden death, be it poison or other clandestine means, and, without the modern means of chemical analysis to know when they had been used or how it functioned, believed it was magical. ${ }^{2}$ Richard Gordon frames his brief discussion on the trials as one where the state power and popular concerns of pollution combined to result in a bloody quaestio. This pollution took the form of disease and explains the writing of later jurists, who conflate venenum with both poisons and medicines. ${ }^{3}$ Other scholars have generally followed one of these three thought processes and will be referenced where appropriate. Where this study differs from others is that, by delving into the trails of Livy and attempting to understand the context wherein they occurred, we do not have to worry about making them fit into a work interested in Roman magic or magic in law.

This said, some qualifiers must be provided. This thesi is not an investigation of every instance of veneficium, nor is it even concerned with every large-scale investigation or accusation of veneficium. Such a study, unfortunately, is beyond the scope of this thesis. While we begin with a long discussion of the language of veneficium and its associated words over time, we do this merely to equip ourselves to investigate Livy more thoroughly. This means

\footnotetext{
${ }^{1}$ Kaufman 1932 156-57.

${ }^{2}$ Graf 1997 46-49.

${ }^{3}$ Gordon 1999 254-57.
} 
that we will not be looking at similar accusations of veneficium in Cassius Dio, where he informs his reader of a rumour that the effects of the Antonine plague have been magnified because people across the empire are in the streets spreading poisons (Cass. Dio. 72. 14. 3-4; 67. 11. 6), or Ammianus Marcellinus, who describes a bout of spells, sorcery, and adultery in Rome between 370-371 (Amm. Marc. 28. 1. 4ff).

In regards to translations, they are my own and unless otherwise referenced. For longer passages I have opted to include an English translation in the footnotes, while short phrases or individual words I have left without a translation. Additionally, for the first case of veneficium in $331 \mathrm{BC}$, I have included the passage from Livy in its entirety and a translation in the appendix. The passage is the longest single passage that discusses veneficium in Livy and its inclusion as an appendix is intended to allow the reader to consider my analysis of individual sections in the context of entire passage.

We should also acknowledge that, while this thesis will use the terms "magic" and "witchcraft" interchangeably, both are problematic. Debates over the precise meaning of "magic" have been present in the scholarship of ancient history for generations and will not be resolved here. ${ }^{4}$ The equation of witchcraft with magic suits the purposes of this thesis in that neither are inherently evil, though I readily admit that those scholars who specialise in the field of magic in the ancient world may not be satisfied by this. This said, it is a small comfort that those scholars who declare their opposition to the use of "magic" in scholarly work, are themselves are forced to use it. ${ }^{5}$ Magic and witchcraft are understood in this thesis to describe the means by which a person, who possesses special powers or knowledge, uses these possessions to make a tangible though unexplainable effect. This study does use "divination" and "necromancy," but only to explicitly describe the prediction of future events

\footnotetext{
${ }^{4}$ Despite some developments following its publication, a good summation of popular perspectives on this topic in academia can be found in: Cunningham 1999.

${ }^{5}$ A point noted by Versnel 1991, 181.
} 
or communicating with the dead, respectively, though there occasional association with venefecium does not mean that they are synonyms

The first chapter will deal with the language of veneficium. While often considered to be mired in ambiguity, this thesis argues that this interpretation on veneficium is incorrect. While it is true that veneficium and its associated words evolved and developed a variety of meanings time, by tracking its development we can actually gain a distinct understanding of what the language meant when Livy was writing, in his subject matter's time period (the fourth and second centuries), and how it has been understood in modern scholarship. By doing this we can also dispel the general belief seen in scholarship that veneficium was an ambiguous term. Instead, considering its context in Livy, we can understand veneficium with a greater clarity.

This clarity will allow us to read the investigations of veneficium in Livy free from any later interpretations of the words. In doing so, we see that Livy appears to remain largely faithful to his source material, though was definitely inspired by understandings of veneficium in his own time. We also see a number of motifs paired with veneficium.

When we consider the subtle moralistic tones so often present in the annalistic tradition and the themes that Livy employs in his descriptions of veneficium we can see that he might imply to his reader that these quaestiones were societal responses in a period of moral decline. This is particularly clear when we consider how the majority of the cases of veneficium we see in Livy are condensed into the second century $\mathrm{BC}$, a period of drastic social and cultural changes in Rome.

Considering veneficium panic and prosecution as a societal response to fear is not a great leap. The fields of anthropology and sociology have already created theories and models that explain how society can respond with inquisitorial accusations to a real or perceived threat to their cultural and social norms during times of stress. This, ironically, is principally found in the study of witch hunts. While veneficium has no magical connotations in Livy's quaestiones, neither does a witch hunt. Instead a witch hunt merely is used to describe the 
mechanism by with a society can identify a perceived threat, i.e. the witch, and resolve this threat by seeking out and destroying it, i.e. the hunt. In doing these things we can view the investigations into veneficium of the second century as indicative of a society struggling to come to terms with rapidly evolving and shifting cultural and social forces. 


\section{Chapter One: Poison, Potion, or Magic?}

The first chapter of this thesis is focussed principally on definitions. By defining veneficium and its associated language we can gain a better understanding of how the Romans understood criminal offenses which facilitated the large scale investigations that we see in Livy. In doings so we also gain insight into the contradictory modern scholarship on the topic. In its most basic form veneficium is a compound noun describing any activity that yields venenum and can include not just the manufacture its, but also its use. Therefore, any practitioner of veneficium was a venficus or venefica. By first examining the crime of veneficium from a legal perspective we may better understand what happened in Livy's mass trials and also see gradual changes in the legal interpretations of veneficium reflected an evolution in how the word was understood and used in wider society. In the case of veneficium and its associated language, we see the words almost exclusively referring to poison and poisoning, and developed over time to become increasingly associated with magic. Furthermore, we can see that while the modern understanding of the word venena is considered neutral, requiring an adjective to specify whether it was salubrious or poisonous, this was a later development and not present when the quaestiones in Livy occurred. By delving into these definitions we can gain insight into what veneficium meant when Livy was writing, in the fourth and second centuries $\mathrm{BC}$, and understand why modern scholars are hesitant to discuss these investigations in-depth.

Veneficium and its associated words are generally considered by scholars to be ambiguous, with a number of contradictory potential meanings, which could describe both good and bad actions. The standard lexica, the Oxford Latin Dictionary and Lewis and Short: A Latin Dictionary, both provide definitions of venenum, the product of veneficium, to mean 
poison, medicine, or magical concoction. ${ }^{6}$ This interpretation has been accepted by a number of scholars who have used this to understand the Lex Cornelia de sicariis et veneficiis as a criminal code that facilitated the prosecution of magic. ${ }^{7}$ This claim appears to be correct in the Imperial period where this code was certainly used to prosecute magic in at least two instances. ${ }^{8}$ Where classicists falter is that they largely fail to discuss anything regarding veneficium earlier than the Lex Cornelia. Perhaps this is because of the ambiguity of veneficium means that quaestiones in Livy are difficult to analyse and they are relocated to something of a curiosity in sources that discuss magic more generally. This is certainly the case in Fritz Graf's Magic in The Ancient World, who summarises the investigations in a page, argues that any sudden death, be it disease or natural causes, for which there was no apparent cause was liable to be called veneficium. In this sense, a death that was not properly prepared for and caused disruption to daily life was potentially veneficium. ${ }^{9}$ Richard Gordon frames his brief discussion on the trials as one where the state power and popular concerns of pollution combine to result in a quaestio. This pollution took the form of disease and explains the writing of later Jurist, who conflate venenum with poison with medicines. ${ }^{10}$ Matthew Dickie in Magic and Magicians in the Greco-Roman World does not mention any instances of veneficium prior to the Lex Cornelia and discounts most instances of veneficium prior to the later Republic on the grounds of the terms ambiguity. ${ }^{11}$ While these approaches provide some of the longest discussion on the topic, they are a small part of a larger work with a focus on magic. However, when we consider precisely what veneficium and its associated words meant, we see that the quaestiones

\footnotetext{
${ }^{6}$ Oxford Latin Dictionary 1968 2027-8; Lewis and Short: A Latin Dictionary 1987 1967-8.

${ }^{7}$ Pharr 1932, 269-95; Smith 1978; Phillips 1991 260-76; Graf 1997 46-7; Beard, North, \& Price 1998; Dickie 2001 145-50.

${ }^{8}$ The trail of Numantina in 23/4 AD (discussed elsewhere in this chapter), for driving her husband to insanity by carmen et veneficium (Tac. Ann. 4. 22), and the very humorous trial of Apuleius of Madaura in 158/9 AD at Sbratha in Africa and recorded in his Apologia. Here he was accused of using magic to gain the favor of a wealthy old widow who then left a significant amount of her wealth to him in her will.

${ }^{9}$ Graf 1997 47-8.

${ }^{10}$ Gordon1999 254-57.

${ }^{11}$ Dickie 2001145-6.
} 
of Livy are not magically, but are a rich source of knowledge armed with the correct understanding of veneficium.

While the investigations into veneficium seen in Livy will make up the majority of this thesis' second and third chapter, some mention should be made here of what Livy records as the first incident of Veneficium in Rome. In the 331 BC when leading citizens died of the same symptoms (8.18.1). The Roman state decreed that these deaths were not related to disease, as Livy himself suspects but rather to malicious acts (8.18.2). During the following investigations, 190 women were executed after being found guilty on charges of venefecium (8.18.1-13). This case is in many ways similar to the investigations, quaestiones, which occurred in the second century where thousands were executed. While chronologically these are the earliest instances of veneficium there is little information in Livy about precisely what the crime of veneficium was, nor what a venefica or venena was. The basis of our knowledge of veneficium as a criminal offense prior to the promulgation of the Lex Cornelia de sicariis et veneficiis is fraught, but we can see glimpses of an earlier conception of veneficium in the reconstructed law.

There is much that can be gleaned from the Lex Cornelia de sicariis et veneficiis about the actual crimes that people were prosecuted for in Livy's quaestiones. The original Lex Cornelia was one of a number of laws passed in 81 BC during L. Cornelius Sulla's reign. His legal reforms reorganised and consolidated the system of standing courts, quaestio perpetuo. ${ }^{12}$ While none of the statutes of the Lex have survived in their original sense, later quotations and references can be used to reconstruct parts of the law and provide a sense of others. ${ }^{13}$ The evidence indicates that the original Lex Cornelia had at least six sections, three of which we

\footnotetext{
${ }^{12}$ Though we should also note that a permanent court for processing cases for veneficium existed prior to the Lex Cornelia and was an evolution of these quaestiones. We know this because an inscription dated to $98 \mathrm{BC}$ by C. Claudius Pulcher recorded the presence of iudex quaestionis veneficiis (ILS $45=$ Inscript. Ital. XIII. 3. 70b), and Cicero eludes to the existence of this court in 84 BC (Inv. 2.58-60) for more see: Brunt 1998 260-1.

${ }^{13}$ A more in-depth discussion of these courts both pre- and post-Sulla can be seen in Brunt 1998 216-22.
} 
can confidently claim to understand. The first section pertained to those "armed with a weapon for the purpose of killing a person or perpetrating a theft," as well as those who killed or arranged for someone to be killed; its purview appears to have been restricted to cases in, and within one mile, of Rome. The fifth section, and the one that most concerns us here, dealt with those those involved in the production and administration of dangerous drugs (venenum malum) and will be discussed below. The sixth section concerned people who caused someone to be wrongly condemned on a capital charge. There is no evidence of the contents of sections two through four, although it is very likely that one of them concerned cases like those in section one that occurred more than one mile from Rome. ${ }^{14}$

In the sections which are known to us, it seems apparent that this law was not a new invention, but rather an exercise in combining and bundling pre-existing laws into thematically similar groups. The obvious connection between the attested crimes is murder: the first section clearly dealt with violent forms of murder, the sixth against the manipulation of courts to condemn an innocent person of a capital crime, and the fifth with the use of venena to kill. Yet there may have been other considerations. It should be noted that the clause concerning sicarii dealt not only with actual killing but also with the possession of implements "for the purpose of killing a person or committing theft." The term sicariis implied premeditation, and so can be read as 'assassin' rather than 'murderer., ${ }^{15}$ We therefore see a more precise connection between the two laws: not any murder, but a wrongful death through forethought and planning. ${ }^{16}$ Knowing now the theme of the Lex Cornelia, we can delve deeper into understanding the specific crime and definition of veneficium.

The original text of the Lex Cornelia de sicariis et veneficiis is lost but can be partially reconstructed from later citations and allusions. The fifth section of the Lex Cornelia addressed

\footnotetext{
${ }^{14}$ I follow the reconstruction by Ferrary in: Ferrary 1991 417-34. Ferrary favours "veneficiis" and not "venficiis" that was posited by Cloud. See: Cloud 1968 140-1.

${ }^{15}$ The clause is attested by Uplian (Coll. 1.3.1), and Marcian (Dig. 48.8.1). Cloud translates sicarius as “gangster." J. D. Cloud, 'How did Sulla style his Law de sicariis?' The Classical Review, 18.

${ }^{16}$ J. B. Rives 2003 318-319.
} 
veneficium and has been reconstructed from Cicero. Its text is given as follows:

De eius capite quaerito qui hominis necandi causa venenum malum fecit fecerit vendidit vendiderit emit emerit habuit habuerit dedit dederit (Clu. 148). ${ }^{17}$

Here the law clearly explains that the crime of veneficium was the use of criminal action (i.e. the use of venena mala) and intent (i.e. to kill). However, its nuances remain unclear. In order to have a proper idea of the meaning of the law, we must examine venenum and veneficium as is exists in the literary and legal evidence.

The most basic meaning of venenum is poison. But the widely held view in scholarship has followed the well known pronouncements of Marcian and Gaius in the Digest that, like the Greek фápнакоv, venenum was neutral (Dig. 48.8.3 \& 50.16.236). ${ }^{18}$ Both the language of the Lex Cornelia itself which contains "malum venenum," and a quotation from Sallust are often used to support this association (Cic. Clu. 148; Sall. Cat. 11.). However, a closer examination of these sources reveals that they do not demonstrate the word's neutrality and reveal a great deal from the Lex Cornelia itself.

In his monograph on the Cataline conspiracy, Sallust wrote ea quasi venenis malis inbuta corpus animumque virile effeminat (Sall. Cat. 11). ${ }^{19}$ Upon first glance this phrase asserts the neutrality of venena by requiring its pairing with malis to express its corruptive and toxic characteristics. But the phrase "malis venenis" is more complex and can be interpreted in four ways. First, this may be an expression of Sallust's own creation, although this seems unlikely as there are few other accounts of this pairing. Secondly, Sallust is referring to an earlier, unattested idiom which has been lost. Which, is impossible to prove. A

17 "Let there be an investigation on a capital charge in the case of him who for the purpose of killing a man has made or will have made, has sold, or will have sold, has purchased or will have purchased, has possessed or will have possessed, has given or will have given noxious poison." This reconstruction and translation is found and discussed in: Ferrary 1991426.

${ }^{18}$ Examples of this neutrality in scholarships include: Graf 1997 46; Pharr 1932 272-3; Mommsen, 1955 635-6; OLD 2027.

19 "It, as if tainted by wicked poisons, weakens the body and the mind." 
third possibility is that it may have a shared a common origin with the legal traditions upon which Gaius and Marcian would later rely for their comments on the Lex. Though delineating whether the legal tradition that they were writing on referred to comments on the Lex Cornelia or to the XII Tables cannot be answered definitively. ${ }^{20}$ Finally, the term may simply be a quotation from the Lex Cornelia itself if we presume Sallust was familiar with the law, as we would expect a respectable Roman noble to be. The most straightforward answer is that Sallust's phrase was not an idiosyncratic invention, but, like the later legal commentators, indebted to the Lex Cornelia. As such, we cannot be so sure that the neutrality of venena existed prior to the the Lex Cornelia but can only safely assume that this notion existed at the time Sallust was writing in the first century BC.

Furthermore, the language of those later jurists must likewise be considered in the context of their own time. For such an examination shows that they reflect linguistic concerns at the time of their production rather than of the Lex. The Lex Cornelia is further discussed in the Digesta by the jurists Gaius and Marcian and provides a glimpse as to how the Lex was understood in the ancient word, though is not without problems. The extracts in the Digesta were carefully selected because they were deemed the most relevant to it's creator in the $6^{\text {th }}$ Century AD and they do not present the full breath of jurists comments on any given law (which we know could be contradictory). ${ }^{21}$ Nevertheless, flawed as they might be, in lieu of better evidence we must use them. Regarding venenum, Gaius wrote:

Qui venenum dicit, adicere debit, utrum malum an bonum; nam et medicamenta venena sunt: quia eo nomine omne continenter, quod adhibitum naturam eius, cui adhibitum esset, mutat. Cum id quod nos

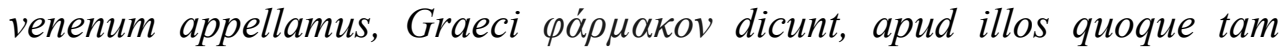

\footnotetext{
${ }^{20}$ Their argument will be looked at shortly. To summarize, it purports that the quotation comes from his commentary on the XII Tables but Hoffman asserts that no such context for this statement exists and it is impossible to really know if the quote preserved in the Digest was a digression. See: Hoffman 200274.

${ }^{21}$ For more see: Watson 1998 4-10.
} 
medicamenta, quam quae nocent hoc nomine continentur. (Dig. $50.16 .236)^{22}$

This extract has three immediate implications. The first of which is that there exists a semantic connection between venenum and medicamentum, with the latter being ambiguous in Latin. In terms of categories, we must pay close attention to the phrase "nam et medicamenta venena sunt." Following Hoffman, we may read this passage as "for medicamenta are also venena." This interpretation conforms to our conclusion that Gaius here is asserting that the neutrality of venenum, and means that nam is now indicating the clause it precedes is referring to the previous clause and providing further explanation. If this approach is taken then it can read Gaius as stating that venenum is ordinarily negative, and that in the following sentence he stresses that venenum can in fact be medicamentum. Thus, Hoffman argues, Gaius is countering the commonly held belief that venenum was negative by saying that is is neutral, contrary to the ancient reader's expectation (reinforced by the emphatic et). ${ }^{23}$ This would suggest then that venenum as a negative was the norm in the ancient world and not as morally ambiguous as the lexica attest.

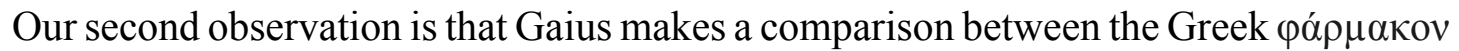
and Latin venenum. This component of Gaius' argument is important because he supports his assertion that venenum is neutral on the basis of the definitely opaque Greek. This is argued on

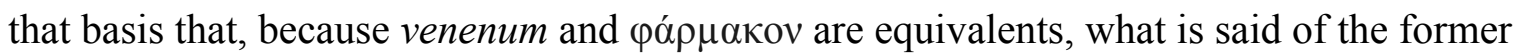

22 "He who says "venenum," must indicate whether it is good or bad; for even medicines are venena because with that word everything is meant that when employed changes the nature of that for which has been employed. Because what we call venenum the Greeks call $\varphi \alpha \dot{\rho} \mu \alpha \kappa o v$, among them medicine as well as harmful drugs are implied with that name."

${ }^{23}$ Hoffman effectively argues that reading it in the standard Latin subject-predicate, then Gaius is saying that venenum is neutral and that medicamentum can be considered venenum. In this reading the emphasis is on the et because the statement would be contrary to expectation. But, medicamentum in the standard lexica is clearly and unambiguously a neutral term. Accepting this means that, would mean that the et would no longer emphasis the difference between theses terms and say something to the effect of: "medicamentum (neutral) are indeed venena (also netural)." But, if venenum is definitively negative, then what is displayed in the Gaius' account was that there existed a class of medicamenta (neutral) that were classified as venena (negative). Thus a malicious medicine. See: Hoffman 2002, 75-6. 
applies to the latter. This equation of the two is significant for Giaus as it links venenum to Homer, whom he subsequently references (Hom. Il. 4.218, 230; 11.515). For, as Homer spoke of good and bad $\varphi \alpha ́ \rho \mu \alpha \kappa \alpha$, so too does Gaius speak of good and bad venenum. The implications of this would provide providence to his claim, but it is obvious that this connection, while believed at the time it was written, did not exist and was an anachronistic projection by Gaius. ${ }^{24}$

Lastly, we must consider that this quotation is taken from a section that deals with Gaius' commentary on the XII Tables. What is particularly curious about this point is that there is no attested portion of the XII Tables that relates to venenum. One possible interpretation is that Gaius' writing was triggered by the similarity between the phrase malum carmen, which is attested as having been on the XII Tables (Cic. Clu. 148), and mala venena in the Lex Cornelia (Dig. 48.8.3). The difference here is that carmen is a neutral word, and the addition of malum was necessary to differentiate a song from a curse or defamation. ${ }^{25}$ Alternatively, the use of a negative adjective could simply be emphasising its negativity rather than specifying the nature of an otherwise ambiguous word. For example, when we consider malum pestam, mala sacabies, malum cruciatum the adjective is simply stressing the badness of the noun without any alternative positive conception. ${ }^{26}$ Despite being from a variety of genres, a positive pesta or neutral cruciatus is entirely implausible. Considering this we see that venenum was a negative word word regardless of the attestations of later authors and jurists and thus we should consider that while venanum may well have be regarded as neutral in Livy's own time, it was almost certainly emphatically malicious in the quaestiones de veneficiis of fourth and second centuries that are the topic of this.

Having argued that venena was originally malicious we should consider how it evolved to become neutral to shed further light on its evolution and understand how modern scholarship is mislead by later definitions that differed from those of the fourth through

\footnotetext{
${ }^{24}$ Hoffman 2002, 76-7.

${ }^{25}$ Rives 2002, 279-88

${ }^{26}$ Cic. Phil. 6.12; Hor. Ars. P. 453; Aul. 459.
} 
second century. Indeed, considering the neutrality of these words is attested to in the legal realm we should consider how these laws, and commentaries on them, were shaped by the rhetorical schools. In the second century AD writers explored the possibility of venenum possessed a previously unattested ambiguity. Approximately contemporaneous with Gaius, Gellius' Attic Nights notes in a section about on ambiguous words that "“'Periculum" etiam et "venenum" et "contagium" non, uti nunc dicuntur, pro malis tantum dicta esse multum exemplorum huiusmodi reperias" (Gell. NA. 12.9.2). ${ }^{27}$ Gellius' example here illustrates how the definition of venenum in the $2^{\text {nd }}$ century rhetorical schools was flexible and that there were concerns by him and his contemporaries in how these words were used in trials, but it fails to indicate for how long these words were understood to be ambiguous but may suggest an earlier negative form. In fact, the evidence available to us would suggest that this ambiguity is derived from the rhetorical schools of the social elite where its was developed, honed, and exploited to win legal cases.

The rhetorical tradition is the richest source of evidence for the supposed ambiguity of venenum and possibly the place where its vagueness of born. In these texts any substance that was administered to a person could be interpreted as venenum depending on several factors such as who administered it, their intent, and the result. As with Gaius, we find a juxtaposition of venenum and medicamentum, but here its ambiguity is discussed forensically and not judicially. ${ }^{28}$ This is to say, while a defendant might claim that a substance was a medicamentum, a plaintiff might claim it was a venenum. Quintilian, for examples offers this advice:

"Quare negat venenum esse qui pro rea dicit? Quia non occiderit neque sit

\footnotetext{
27 "That 'trial' and even 'poison' and 'contagion' were not, as they are used now, said only with a negative meaning, you may learn from many examples of that usage." It is interesting to note that, despite Gellius' insistence that many examples could be found in his day, regarding venenum, only two survive from Classical Latin: Cic. Clu. 148, and Sall. Cat. 11.3.

${ }^{28}$ Through the pairing of these words goes back at least to Plautus: item ut Medea Peliam concoxit senem, quem medicamento et suis venenis dicitur fecisse rusus ex sene adulesentum, item ego te faciam ("similarly, just as Medea cooked Pellas, whom she is said to have changed from an old man into a young one, with her medicine and poisons, so I shall do this to you.") Pseudo. 869-72.
} 
mortiferum. Quare dicit venenum esse qui accusat? Quoniam medicamentum sit etefficiat aliquid contra naturam. Ergo non est satis id modo videri venenum quod occidat, sed haec omnia venena sunt [quae]." (Quint. Ep. ad Tryph. 246.3). ${ }^{29}$

Here the emphasis is on the physical effects that the substance has on its consumer and that venenum was the preferred term for the accuser while medicamentum was favoured by the defendant. Furthermore, Quintilian, like Gaius, when stressing the ambiguity of venenum, explicitly says that venenum is a medicamentum. Likewise, Seneca the Elder, writing decades earlier, identifies a similar semantic connection. In this instance, a son is caught red-handed medicamentum terens, preparing a drug, and accused of parricide. To justify his actions, he cites historical examples comparing the "malum medicamentum" of Mithridates to the venenum that Demosthenes consumed (Sen. Con. 7.3.4). Like Quintilian, Seneca illustrates the juxtaposition and equation of venenum and medicamentum. Furthermore, the fact that venenum was comparable to malum medicamentum entrenches the notion that medicamentum was ambiguous and required modification, whilst venenum was completely negative. Later still, in Pseudo-Quintilian we have two examples which are likely contemporaneous with Gaius that are also consistent with this evidence. ${ }^{30}$ In one example we see venenum referred to as odii medicamentum, in the other, the speaker when discussing a situation wherein the accuser administered venenum without death, observes that "bibisse te medicamentum probare non posses, nisi meretrix fateretur (sc. se dedisse)" (Quint. Ep. ad Tryph. 15.5). ${ }^{31}$

Taken as a whole, the evidence of the rhetorical schools from Seneca through to Pseudo-Quintilian remain consistent and proof that venenum and medicamentum were near,

\footnotetext{
29 "Why does the advocate for the defence deny that it was poison? Because it did not kill, it is not death-bringing. Why does the prosecutor say it is poison? Because it is a drug and produces something against nature. Therefore, it is not enough that merely what kills should be regarded as poison, but everything is poison.” See: (tr.) Bailey, 2006, 21.

${ }^{30}$ Sussman 1994, 6 .

31 "You would not be able to prove that you had drunk the medicine if the prostitute did not admit it."
} 
but not perfect, synonyms. Though, while venenum possessed a consistently negative sense, we see that it is medicamentum required modification. Thus, aside from the implicit and explicit recognition of venenum's fundamentally negative connotation, the rhetorical schools make it clear that there was a tenuous equation between the venenum and medicamentum. Considered in relation to Gaius, this is because medicamentum, and not venenum, is the neutral word capable of modification to make it either positive or negative. In essence, the development of the inherently negative venenum's ambiguity and neutral tone is derived from its eventual association with medicamentum which was a neutral word, though this association was a later development and not present at the Lex Cornelia's creation nor in the laws that preceded it.

Furthermore, we may note that rhetorical strategies attempted to capitalise on the ambiguity and neutrality of substances classified as venenum. In other words, although venenum itself does not occur with a neutral sense in declamationes, the rhetoricians were wily enough to appreciate that a lack of clarity around motives, substances, and administration could be exploited to cast venenum as a medicamentum, remedium or viceversa for the benefit of the speaker. Returning to the comments of Gaius, and by extension Marcian, we now know that they cannot be taken at face value. Rather, by virtue of chronological, rhetorical, and social context, they appear to be the product of the rhetorical system and not resolute statements illuminate the traditional legal understanding of venenum in the original Lex Cornelia, nor its understanding in the investigations of veneficium in Livy. And so, we may now say emphatically that malum does not imply venenum was morally ambiguous as the later jurist record, but emphatically reaffirms its negativity. Therefore, venenum has always meant poison and has always been negative.

Having considered the above then we can surmise that when the Lex Cornelia was originally penned, venenum, and by extension veneficium, were understood to mean poison and was always malicious. Its later equation with the production of medicine was most likely 
an invention by later rhetoricians like Quintilian in the first century AD. It is because this false equivalency had become such common place by the sixth century, that it simply came to mean as much and thus later jurists argued that venenum required qualifications to counter this ambiguity in literature. Yet, while we can understand the ambiguity of the Lex Cornelia was also the law by which people came to be prosecuted for magic.

While later jurists regarded the Lex Cornelia as encompassing magical activities, this is rarely seen in the veneficium or its derivatives appear in magical contexts during the Republic. The earliest examples of veneficium in the magical sense are Republican, but it is used in a specific way that differentiated magic from poison. In the Brutus, Cicero relates a story of alleged witchcraft. Gnaeus Sicinius, an incompetent speaker, forgot the case he was pleading and accuses Cicero's client, Titinia, of bewitching him: idque veneficiis et cantionibus Titiniae factum esse dicebat (Brut. 218). ${ }^{32}$ The clear implication of this passage is magical and serves as the the stereotype of veneficium when it is used in a magical context during the Republic. It is only when Veneficium is paired with oral activities that witchcraft is indicated, alone it means poisoning. Therefore, we should consider the presence of magic Tacitus uses a practically identical phrase to describe charges brought against Numantina. While ultimately acquitted, she was accused of having driven her husband mad by carmena et veneficia (Tac. Ann. 4.22). In another case in Tacitus, Domitius Afer accused Claudia Pulchra of adultery and the use of veneficia in principem et devotiones (Ann. 4.52), while Lepida, in her attempted murder of Claudius' wife also uses devotiones in concert with venena (Ann. 12.65.). In these instances, veneficium is clearly magical which is expressed with the reference of a verbal component, either carmina or devotiones.

This is not to say that veneficium had lost its poisonous meaning yet, but illustrates that it was transitional in this period. We see a more straightforward example poisoning in Tacitus' description of the famous poisoner Martina, where these oral pairings are absent and

\footnotetext{
32 "And he said that this was done by the veneficium and incantations of Tititina."
} 
she is simply infamem veneficiis (Tac. Ann. 2.47). Nor was there any doubt that her skills appear firmly rooted in pharmacology. ${ }^{33}$ Likewise, Tacitus also refers to only veneficium when describing Martina's suicide by poisoning: famosa veneficiis Martinam subita morte Brundisii exinctam, venenumque nodo crinium eius occultum nec ulla in corpore signa sumpti exitii reperta $\left(\right.$ Ann. 3.7). ${ }^{34}$ It is in this way that we see how Tacitus maintained the same linguistic tradition employed by Cicero two centuries earlier. Veneficium alone referred to poisoning; but when paired with language referring to an oral or verbal act indicated witchcraft. $^{35}$

Pliny records a trial of veneficium in his Natural History that is also worth noting because it. The freedman, C. Furius Chresimus, was brought to trial by his neighbours because his crops appeared to be out of proportion to the small size of his property and he was accused of using veneficium to have achieved this. The language that Pliny uses is particular interest: "in invidia, erat magna, ceu fruges alienas perliceret veneficiis." $(18.42-3)^{36}$ This story, though dated to $191 \mathrm{BC}$ used language suited to a much later period. ${ }^{37}$ Clearly veneficium can only be read as magic here, and yet, there is no pairing with any oral language. This marks the passage as the earliest instance of veneficium alone being used to

${ }^{33}$ Indeed, Piso is left "opperiens aegritudinem" "awaiting the outcome of illness" (2.69); Saevam vim morbi augebat persuasionem veneni 'the suspicion of poison increased the violence of the disease" (2.69); praetuleritne veneficii signa "whether or not he exhibited the signs of poisoning (2.73) The final quotation merely relates to whether or not Germanicus showed the symptoms of poison which seemingly depended on whether one was a supporter of Piso or Claudia. Suetonius and Pliny both believed he was poisoned (Suet. Cal. 1.2; Plin. HN. 11 187).

34 "It was widely rumored that the notorious poisoner Martina, who had died suddenly at Brundisium; that poison was concealed in a knot of her hair, and that no symptoms of suicide were discovered on her person."

${ }^{35}$ Further too this point, Quintilian proves helpful. In his Institutio Oratoria, he instructs orators to exploit the alternative meanings where possible. He suggests that there was confusion if carmina magorum, the chants of the magi, were veneficium, and suggests this should be exploited (7.3.7). He makes a similar claim about amatorium and veneficium (7.3.10). This all suggests there was a deep confusion in how the word was understood in the late first century AD.

36 "he was the object of much envy allegedly for charming the crops of others with his witchcraft."

${ }^{37}$ This can be dated because Pliny identified Sp. Albunis, as the presiding magistrate. We can either assume then that this event occurred in 334 BC during the consulship of one Sp. Albinus, or during the aedileship of a man with the same name in 191 BC. See: Broughton 1951353. 
indicate magic. This use of veneficium when paired with an oral component might have its origin in the Twelve Tables. The Twelve Tables specifically includes as a criminal statute "excantare fruges alienas." In the case of Chrisimus, it would appear that this was the statute that was apparently violated. ${ }^{38}$ The oral component of magic, evident in the Twelve Tables with the verb excantare is normally indicated by words such as incantamentum or cantio, to cite two examples. For example, the pairing of veneficia et cantiones or a variation of it, is normal and required to express in Classical Latin the idea of magic because veneficium refers to the materia magica while the cantiones referred to the oral component of casting magic. It is in this mould that we see veneficium being used to conflate both the material and oral in a way that would not be seen until much later like in in the jurist Paulus (Paul. Sent. 5.23.15).

It is important reiterate that Roman legal system was far from static, and was instead a fluid system in a state of constant evolution. Statutes underwent continual alteration principally by three means: the application of the law during trials resulting in precedence, the creation of new laws that modified or superseded earlier ones, and the work of jurists in interpreting and codifying laws. ${ }^{39}$ As a result, the scope of the Lex Cornelia grew and developed in such a way that its original specific application to poisoning, grew to include the magical. For instance, there was a tendency to use the Lex Cornelia for malicious activities effected by supernatural means other than veneficium. For example Modestinus records that, a senatus consultum of an unknown date, ${ }^{40}$ decreed that anyone responsible for mala

\footnotetext{
${ }^{38}$ If we assume that the quaestio, the focus of the second and third chapters, was standard for prosecuting veneficium at the time of Chresimus, we would expect him to stand before a quaestio. OInstead it appears that he was judged by a jury in accordance with the provision of the Twelve Tables, that is, an existing law concerned with a specific magical art, suggests that veneficium did not yet encompass that activity.

${ }^{39}$ Rives is responsible for identifying these three trends, though does note exceptions. See: Rives 2003 $320-21$.

${ }^{40}$ Rives argues this can be dated to prior to the second century AD. Modestinus wrote approximately between $225-250 \mathrm{AD}$ so the $S C$ must have been promulgated prior to this. Additionally, using Talbert's research, jurists were more likely to refer to imperial orationes then senatus consulta for laws passed after the reign of Hadrian would also suggest an earlier date. See: Talbert 1984 67-81.
} 
sacrificia, "wicked sacrifices," should be condemned under the Lex Cornelia (Dig. 48.8.13). While there is no definition provided for mala sacrificia, an argument can be made that they were evoking curse tablets. ${ }^{41}$ On the other hand, the Lex Cornelia had also expanded to include malicious actions and not just murder. Quintilian records that there was debate whether venenum could include love potions under the Lex Cornelia (Inst. 7.3.10,7.3. 30.7.8.2, \& 8.5.31), ${ }^{42}$ and other evidence suggests that venena intended to cause madness might fall under this law too (Inst. 9.2.105). ${ }^{43}$ So it is that we see the purview of the Lex Cornelia gradually expanding.

In fact, there are no examples of veneficium alone referring to magic in the works of any Republican author, Pliny is our earliest source for this practice. This is why the standard lexicons do not include any citations to support magic as the principal or primitive meaning of veneficium. Indeed, the OLD and LS cite the previously mentioned passage from Cicero's Brutus without noting the importance of the canto, without which veneficium simply suggests poison. It appears that the apparent oral tradition of magic uses is what is of the pattern that we have now seen argued in Tacitus. After Tacitus it seems that veneficium was used with infrequency, as it more or less seemingly disappears from standard speech. Tacitus illustrates that in the late first and early second centuries $\mathrm{AD}$ the understanding of veneficium was evolving and becoming associated with magic.

Pausing here, we should also note some of the qualifiers of the practitioner of veneficium. Having considered veneficium and venenum we should consider the person who engaged in the traffic, manufacturing, or use of venenum, the veneficus or venefica. Quintilian

\footnotetext{
${ }^{41}$ Cf. Dig. 5.23.15. Also, it is possible to see devotiones being prosecuted with the laws against veneficium during Tiberius' reign as Tacitus too informs his reader that Piso was accused of murdering Germanicus by means of devotiones and venenum (Ann. 13.22.2).

${ }^{42}$ Marcian (Digesta 48.8.3.2) also says that amatorium, love potion, is a type of venenum, but also says that the Lex Cornelia only applied to that venenum intended to kill. See also: Gordon 1999, 256-8.

${ }^{43}$ Quint. Ep. ad Tryph. 14 also outlines a "hate potion" that may be a form of madness in that a state of mind was induced counter to normal. By this logic one might argue a love potion is a madness potion too.
} 
says that a charge of veneficium was more credible when lodged against a woman, ${ }^{44}$ and Pliny agrees with the notion that this was an accepted gender stereotype. ${ }^{45}$ This would explain that, despite the attestation of male venefici, female veneficae are much better represented in our literature. Especially when we consider popular culture. In Latin comedy it seems veneficus and venefica were standard insults. ${ }^{46}$ The following passage of Terence Eunuchus can be taken as representative:

PYTHIAS: Illum eunuchum negant fuisse.

THAIS: Quis fuit igitur?

PYTH: Iste Chaerea.

THA: Qui Chaerea?

PYTH: Iste ephebus frater Phaedriae

THA: Quid ais, venefica? (Ter. Eun. 820-824) ${ }^{47}$

It is noteworthy that the use of venefica here is used to express surprise upon Thais learning something contrary to her expectations. Indeed, this is also seen in Epidicus, where Periphanes refers to his son's lover as venefica (Plaut. Epid. 221), ${ }^{48}$ and, in Rudens, when Gripius calls Trachalio a veneficus upon learning that Palaestra and Ampelisca are freeborn (Plaut. Rud. 1112). The common thread of these examples is that they are expressions of shock and insult. It is also more regularly applied to women than men. Whilst one might be

\footnotetext{
${ }^{44}$ latrocinium in viro, veneficium in femina credas "you would believe a charge of banditry with a man, and poisoning with a woman." Quint. Inst. 5.10.25.

${ }^{45}$ Plin. Nat. 25.10

${ }^{46}$ Dickey 2002, 180 ('lexical versus address earning'),183, 190, 363.

${ }^{47}$ PYTHIAS: They say that it was not the eunuch.
}

THAIS: So who was it?

PYTHIAS: That Chaerea.

THAIS: Chaerea who?

PYTHIAS: The young man, Phaedria's brother.

THAIS: What are you saying, you poisoner?

${ }^{48}$ Dickie 2001 164. Dickie's interpretation of the invocation of venefica as magical in this context may be correct too when considering Ep. 216 and the discussion of courtesans ensnaring newly enriched solders returning from successful campaigns abroad. 
tempted to read an echo of venenum or even magic into these expressions, there is insufficient evidence to assert this conclusion. ${ }^{49}$ Despite the attractiveness of reading more into this epithet, we cannot reach any firm conclusion. On the whole though we see a belief evolving in the second century of veneficium becoming more readily attached to women beginning with Cato and Terence.

Considering veneficium beyond the legal realm reveals an alternative popular understanding of the veneficum and their trade. Horace's character Canidia provides a comic counterpoint to the legalistic understandings of venefecae that have dominated our discussion so far and represented a more common understanding of veneficium removed from the legal domain. Canidia is a frequent but wildly different character in many of Horace's Satires and Epodes. Though her presentation in Horace's work is constantly changing, ${ }^{50}$ she remains a elderly hag throughout. This said, despite being referred to by name in six poems, and frequently being described in modern scholarship as a witch, ${ }^{51}$ Horace never explicitly labels her a venefica, despite performing veneficium. ${ }^{52}$ Instead, it was only scholiasts commenting on Horace's work that called her as much. ${ }^{53}$ In this case, Horace implies she was a venefica by revealing to his audience that Canidia presumes that a more knowledgeable venefica has already ensnared him, "veneficae scientioris carmine" (47-48). In addition to supporting our previously stated claim that veneficium when coupled with a verbal word becomes magical,

\footnotetext{
${ }^{49}$ Dickie has argued that the term was in fact a generic insult in comedy and did not specifically refer to the crime of veneficium in: Dickie 2001 180, 183.

${ }^{50}$ At one moment she is see as the leader of a wicked coven that starve a child so that his organs could be harvested to produce a love potion (Epod. 5), in another a flatulent Priapric statue causes her to panic and abandon her magical activities (Sat.1.8). She is simultaneously a character that Horace used to invoke fear in his audience and an object of derision (Epod. 3), and also easily used as a more generic harbinger of bad luck (Sat. 2.1\& 2.8). Oliensis considers Canidia as one who brings Horatian impotence, and a darker counterpoint of Maecenas who is also frequently features in the Epodes. See: Oliensis 1998 64-101.

${ }^{51}$ Manning 1970, 393-401; Oliensis 1991 107-38.

${ }^{52}$ This is seen in Epode 5 with her frustration that her dira venena fail to make a man fall in love with her (Epo. 5. 61-2).

${ }^{53}$ A point noted firstly in: Paule 2014 754; and expanded in his later work: Paule 2017 17-9.
} 
this sentence also suggests that a more talented peer in her profession has outdone her. ${ }^{54}$ If this interpretation is believed we can assume that Canidia was indeed a venefica and this constituted a popular image of the venficae when Horace was writing in the first century BC.

The references to veneficium in Horace's Epode 17 are just as mysterious. Here Canidia asks talks directly to the Horace as the author and asks:

\section{Inultus ut tu riseris Cotyia \\ vulgata, sacrum liberi Cupidimus}

Et Esquilini pontifex venefici

Impune ut urbem nomine impleris meo? (17. 56-59) ${ }^{55}$

The pontifex venefici, while striking, is vague. While David Mankin proposes that this was a veiled insult invoking the notion that some highfalutin poets considered themselves a type of priests, he fails to address the inclusion of veneficium in this theory. ${ }^{56}$ Maxwell Paule notes the presence of veneficium with curiosity, but ponders whether Canidia is recognising the previously unheard of pontifex venefici was more magically gifted than herself, or, oppositely, being so meagrely empowered, Canidia's evocation of the pontifex veneficium for protection is comical. ${ }^{57}$ In both of Paule's analysis and Mankin's commentary, we are left unsatisfied about the power or scope of veneficium and Canidia's relationship to it. Indeed, it is only the second century scholiast Pomponius Porphyrion that felt the connection was clear enough to

\footnotetext{
${ }^{54}$ it is also possible that in this context venefica might be a term of contempt and ridicule with Canidia insulting a distinct and inferior group of magic users. See: Mankin 1995 135. Mankin goes so far as to propose a possible translation as "dime-store witch." Paule also notes an alternative reading would suggest the opposite with Canidia describing a group of magic practitioners who possess abilities equal to, or greater than, her own. See: Paule 2014754.

${ }^{55}$ Were you going to divulge and ridicule the Cotyian mysteries, those rituals and emerge unscathed?

And, like some high priest of veneficium on the Esquiline, were you to fill the city with my name?

${ }^{56}$ Mankin 1995286.

${ }^{57}$ Paule 2014755.
} 
directly label Canidia a venefica three times (In Hor. Epod. 3.8, 17.2 Sat. 1.8.1). ${ }^{58}$ Yet Porphyrion's sense of the word is unclear here. Perhaps, when considered in relation to his labelling of Medea as a venefica (In Hor. 2.13.3), then we can see venefica used to describe a woman who possesses the ability to controlmen's minds by magical means.

While Canidia is one of the most famous witches of Latin literature, we should also pause to consider Erictho as she is found in Lucan's Pharsalia. The necromancy of Erictho, and her taboo rituals dominates the latter half of book 6 in the Pharalisa. She dwells in tombs after removing the bodies of the original inhabitants (6.510-512). Like Canidia, she is elderly, ugly, with wild unkempt hair (515-520). The depiction of Erictho is excessive, she is so toxic and surrounded by a miasma of death that even the flora dies under her foot (522-3), she harvests and mutilates corpses for eyes, fingernails, and other body parts for ingredients in her concoctions (538-53), and murders so that she can add new spirits to her personal army of the dead (559-60). Most relevant to us though is that she is explicitly labelled a venefica by Lucan (6.580). Considering Canidia and Erictho we see how venefica in ancient popular culture were more flexible characters than in historical or legal texts. Reflecting on our fictional veneficae, we can draw two conclusions. Firstly, we can assume that the characters seen in our literary sources were evocative of a widely understood notion of the venefica, $\mathrm{s}$ imilar to a modern understanding of witch, who possessed a wide arsenal of sinister supernatural powers. These characters illustrate that there existed a form of veneficium in the first centuries $\mathrm{BC}$ and $\mathrm{AD}$ that paired with an oral component was magical.

Continuing through the second century $\mathrm{AD}$ we can see a decline in the use of veneficium it is not its end entirely, and it is during the late empire that we see its final evolution to refer to magic in a general way. Linguistic evidence suggest that the initial $b$ and $v$ in Latin were merging during the $2^{\text {nd }}$ Century $\mathrm{AD}$, in part, because of the homophony that

\footnotetext{
${ }^{58}$ Paule 2014755.
} 
came to exist between veneficium and beneficium. ${ }^{59}$ Obviously, beneficium and veneficium sounded very like, so much so that both Fronto and Apuleius makes puns with these words (Fro. Ep. 1.7.3; Apul. Apol. 102). Nevertheless, veneficium and its related terms do not disappear entirely disappear and were used by learned authors in late antiquity. It is attested to four times in the fourth century Res Gestarum of Ammianus Marcellinus. An examination of Amminaus reveals some interesting conclusions about its later magical development, including that veneficia in the plural becomes shorthand for witchcraft.

Ammianus uses veneficium in relation to charioteers. Ammianus recounts with disdain how several men of senatorial rank had used veneficium in concert with the charioteer, Auchenius (Amm. Marc. 28.1.27). Later the charioteer Athanasius is also accused of veneficia (Amm. Marc. 29.3.5). Evidence that charioteers actually, or at least by reputation, used magic exists in material evidence and imperial pronouncements. There is abundant physical evidence defixiones that were designed to help a charioteer, usually by bringing grizzly misfortune to an opponent. $^{60}$ There is also testimony of the emperor Valentinian, who, in an imperial pronouncements, identifies charioteers as a particularly pernicious group of magical users saying quod si quisquam ex agitatoribus seu ex quolibet alio genere hominum contra hoc interdictum venire temptaverit... (Cod. Theod. 9.6.11). We can then with some confidence say that charioteers, infamous for their use of forbidden and disdained practices to win, were likely using veneficia in a magical context.

We also see the discussion of veneficium as a polluted and tainted craft. Ammianus tells us that Palladius informed on various persons ut artibus interdictis imbutos. ${ }^{61}$ These arts were known to quosdam veneficiorum notitia pollutos (Amm. Marc. 29.2.2). The use of artes and polluisse evoke specific legal understandings of magic in the $4^{\text {th }}$ Century AD. In describing the magical arts, the laws of the late empire are highly moralising. The magical

\footnotetext{
${ }^{59}$ Herman 2000 39; Lindsay 189454.

${ }^{60}$ See: Audollent 1967 473; Lee-Stecum 2006 224-234.

61 "allegedly tainted with forbidden arts."
} 
arts were seen as contaminative and thus polluted the practitioner. This point is most clearly made in the imperial pronouncements of the Emperor Valentinian. In one example he refers to quicumque maleficorum labe pollutum audierit (Cod. Theod. 9.16.6). We also see the emperor referring to magicis artibus (9.16.3), prava confessione (9.16.4), magicus contaminibus (9.16.5), and malus artibus (19.6.6). Obviously the connection here is that that magic here contaminated its users and that these phrase were the standard legal terminology of the time. Considering Ammianus's writing on Palladius, it seems logical that a phrase such as artibus interdictis imbutos was indicative of magic. His subsequent clarification of veneficorum notititia pollutos in its plural form appears to confirm this interpretation (Amm. Marc. 29.2.2).

One way of determining what Ammianus understood what was meant by veneficia is to consider how he discussed cases which were clearly and explicitly poisonings. In his episode regarding the former proconsul Chilo and his wife Maxima, it was alleged that vitamque suam venenis petitam (Amm. Marc. 28.1.18). ${ }^{62}$ In another he retells a story about Publius Cornelius Dolabella presiding over a trail for poisoning. ${ }^{63}$ There the phrase used is venenis necasse. Finally, there is the story of the offer made to a traitor to order Pyrrhus. The phrase veneno necabit infectis is used (30.1.22). In these three instances, Ammianus remains consistent in his use of venenum to designate substance. And, if there is any doubt, we can take in to account not only Cicero's discussion of Pyrrhus episode, but also the statement of Augustine of Hippo, a contemporary of Ammianus, that venenum can only be used to explicitly refer to a drink that causes death (Pelag. 4.4.7). The evidence here points to the use of venenum in the tradition sense of a poison as a substance remained. ${ }^{64}$

\footnotetext{
${ }^{62}$ It is worth noting the similarity of this turn of phrase to Tacitus' Annals 3.23. In the attempted assassination of Chilo and Maxima, the accused were Sericus, an musical instrument maker, Asbolius, and athletic coach, and Campesisi, a soothsayer. While it is tempting to suggest their occupation creates a magical context for the story, it seems more likely that their occupations are used to stress a vast difference in social standing between the poisoners and their intended victims.

${ }^{63}$ Presumably this story takes place shortly after Julius Caesar's death.

${ }^{64}$ See also 28.4.14 for an example of venena as a simile. Also there a number of instances wherein
} 
While we can be quite sure then in our conclusion that veneficium and its associated words originally strictly referred to poison and became gradually associated magic, we have not yet posited why this might have been. While such an endeavour is fraught with presumptions, perhaps the most compelling argument has been made by James Rives. His argument stems from the opinion that, while we would differentiate a poison and magic potion by our ability to scientifically analyse the cause and effect of one but not the other, the Roman's would not have held this distinction. As such, in Rome something might be simultaneously for something to be unexplainable and yet not supernatural. ${ }^{65}$ Instead, the fact that it operated in an unseen and uncanny way is what defined the nature of venenum and by extension veneficium. In this context, he explains that venenum is not as ambiguous as the scholarship suggest, but refers to any naturally occurring substance that, through unexplained means, had an effect on something else. ${ }^{66}$ Where this thesis diverges from Rives is that, while venenum undoubtable operated in an uncanny way from an ancient perspective, it originally referred to that which killed by these mysterious means. Only later did it become associated with medicine, which also operated in a similar way on the human body, and magic. Regardless, the logic of Rives argument still functions to explain why and how veneficium progressively came to be imbued with different meanings over time and eventually came to mean anything that operated in an unexplainable way.

As we have seen, veneficium and its associated words can have a number of meanings, though attestations by modern scholars to the words ambiguity are flawed. We must acknowledge here that much of this chapter relies on the work of others, though the application of the scholarship on chronological periods does illustrate that veneficium was not inherently ambiguous but evolved these traits over time. As we look at the language in our

venenum is contrasted with ferrum. See: Cic. Rosc. Am. 100, \& Tert. Scor. 1.

${ }^{65}$ For examples, see the discussion of why certain plants are medicinal in Cic. Div. 1.13.16. Also see: Phillips 1991 260-270.

${ }^{66}$ Rives 2003 319-320. 
sources we see a clear development of veneficium as a word that initially referred to poisoning, but which came to also mean making or administering medicine, and eventually magic more generally. This evolution was probably in large part due to Roman perceptions of the world that allowed for something to be both unknowable and uncanny without being supernatural. This was manipulated by rhetoricians in the first century $\mathrm{AD}$ to emphasise veneficium uncanny nature to assist their clients. Later this same fluidity facilitated its equation as the material substance that facilitated spells though required its pairing with an oral word to imply magic, eventually in the fourth century we see that, though the word was rarely used, by itself it could imply magic. It is this later understanding that many scholars have used in their work on veneficium and which we, now divorced from, can consider how veneficium was it is described in the instances of quaestiones seen in Livy. 


\section{Chapter Two: Veneficium in the Quaestiones of Livy}

Having gained a comprehensive understanding of our terminology we are now equipped to approach the core topic of this thesis, the Quaestiones de Veneficiis, or inquisitions regarding poisoning, in Rome and the surrounding Italian countryside. This chapter reviews the instances of large scale poisonings and their investigation in this period and, in doing so, illuminate several common trends and motifs. By investigating poisonings in 331, 184, 180, $154 \mathrm{BC}$, we can identify common trends and begin considering a unified reason why investigations gathered so much steam in the first half of the second century and why so many people were executed.

In $331 \mathrm{BC}$, during the consulship of M. Claudius Marcellus and C. Valerius, Livy informs his reader that the first case of veneficium in Rome occurred. Livy's discussion of the veneficium trial in $331 \mathrm{BC}$ is brief. $^{67}$ In this year, a pestilence afflicted Rome and a great number of people died (8.18.1-2). Livy tells us that when leading members of the state fell ill and died of similar symptoms, people begun to suspect foul play (8.18.3). At this crucial moment a female slave appeared before the curule aedile, Q. Fabius Maximus, and was willing to reveal the culprits in return for immunity for prosecution. ${ }^{68}$ The Senate agreed to her request and she is rhetorically transformed from an ancilla into an index or informer (8.18.4). It is as an index that she reveals that poisoning was responsible for the deaths and led Fabius Maximus to the matrons producing the poison (8.18.4-6).

As the story unfolds, the magistrates follow the index and find women in the act of brewing "medicamenta et recondita alia" (8.18.7). ${ }^{69}$ Livy uses medicamenta with a negative connotation here. And yet, true to the pairing explored earlier in this thesis, we see

\footnotetext{
${ }^{67}$ This is attached in its entirety as appendix one

${ }^{68}$ One wonders why she required immunity unless she herself had been involved in the poisoning, though this is speculative.

69 "drugs and other mysterious substances"
} 
medicamenta evoked as an ambiguous equivalent of venena. This is a peculiar decision by Livy as, while the matronae would claim that they were making medicamenta, the index had already claimed they were making venena and the reader is aware of this prior to hearing the matron's defence. Thus we see a clear juxtaposition between the accused and the accuser. In fact, this is further reinforced when the accused make the specific claim that they were creating medicamenta salubria, or "healthy drugs" presumably to counter the effects of the plague $(8.18 .8)$.

When the informer insists on her version of events, the women discuss amongst themselves and agree to consume the potions to prove their innocence. Livy concludes: suamet ipsae fraude omnes interierunt (8.18.9-10). ${ }^{70}$ This final comment introduces another key motif of Livy's veneficium trials, the notion of deceit. The medicamenta the women claim to have been making is a lie, and the women died because of their deception. Following the conclusion of this trail, the attendants of other matrons came come forward to report veneficium resulting in a further 170 Roman matrons being executed (8.18.9-10). The incident concludes with the event being declared a prodigium, the veneficium becoming the result of madness and not criminal intent. ${ }^{71}$ Rites were performed and the matter was resolved with no further outbreaks of mass veneficium for a century and a half (8.18. 11-13). With the death of the matrons by their own hand and with the performance of remedial rites, Livy's account of the first case of veneficium in Rome is brought to a neat close.

Considering this trail in light of our previous chapter casts doubt on the events as they are explained in Livy and suggests that this story is heavily fictionalised. The claim by the matrons that the venenum was in fact medicamentum is immediately reminiscent of the rhetorical practice taught by Quintilian and explored in the previous chapter. By equating the practice of brewing the resolutely bad poison with brewing good medicine, one could create a degree of reasonable doubt in those presiding over the case. However, as we discussed

\footnotetext{
70 "They themselves all perished from their deceit"

${ }^{71}$ The declaration of a prodigy additionally strips the women of agency
} 
earlier, the development of this as a legal argument is not seen until the first century AD writings of Quintilian. While Quintilian wrote half a century after Livy, we may assume then that Livy knew of this legal argument and used it to embellish this case of veneficium. In this case then, the conflation of medicamentum and venenum was not the invention of Quintilian but instead existed prior and simply recorded by Quintilian due to its effectiveness. Regardless of these assumptions, there is no precedent for this sort of defence in the fourth century and surely would have been noted in the other cases of veneficium if it was. Considering our previous chapter, we see veneficium being used in an intentionally ambiguous way which suggests Livy, in our earliest case study, was using actually using an ambiguous understanding of veneficium that was know in his own time, rather than the emphatically evil one we know existed in the early republic. While this provides some evidence for why parts of this story might have been embellished by Livy, it is not the only piece of evidence.

There is also the problem of the language used in Livy that suggests that it was altered in the subsequent manuscripts. The phrase matronasque ea venena coquere $(8.18 .6),{ }^{72}$ is problematic. Harm Pinkster, in Latin Syntax and Semantics, stresses that the effect of ea is anaphoric, in that it refers to something already under discussion. ${ }^{73}$ However, there was no such mention of venena earlier in Livy's story, making it hard to understand ea venena in this particular context. We may therefore conclude that this passage may have been edited at the hands of Livy or one his intermediaries. Furthermore, there is the mysterious character of the ancilla is potentially revealing. For presumably, regardless of the character's lowly status, their importance in the narrative was such that they would be named in this historic first. If we consider the anonymity of the slave as a precondition for their immunity and the potential source of this story, Fabius Pictor, ${ }^{74}$ it may be possible to detect here some here the

\footnotetext{
72 "and that respectable women were cooking these poisons"

${ }^{73}$ Pinkster1990 249-50.

${ }^{74}$ Oakley1998 594-595. Additionally, Oakley suggests the reason Q. Fabius Maximus, plays such 
anachronistic prejudices shared by Pictor and his contemporaries writing in the latter half of the third century. However, an alternative reading of this suggests that the anaphoric ea is referring back to the first line of section 18 and is stressing that, despite Livy's hope that it was not in fact human involvement, and that it was indeed disease that was responsible for the deaths of so many people, the reveal by the ancilla that Roman matrons were responsible means that there can be no doubt that it was people responsible for these deaths.

We should also consider whether this was truly a quaestio and what implications this has on whether the event really happened. The term quaestium sit stands out here (8.11). It suggests that the Livy regarded the matter as having been investigated by a quaestio. A quaestio was a temporary court headed by a magistrate and suited for trials that involved large numbers of defendants. While it would be logical for such a court to have been created, historical evidence for them prior to the creation of the quaestio investigating the Bacchic cults in 186 , and the establishment quaestio perpetua in $149 \mathrm{BC}$, is poor and problematic. Livy records quaestiones established in 413 (4.50.4-51), 314 (9.26.6-22), and 203 (29.20.1-22) to investigate matters in Rome, and a further three in 303 (10.1.3), 207 (28.10.4-5), 204 (29.36.10-12) in the Italian peninsula prior to $186 \mathrm{BC}$. The examples from the early third century are generally believed to be the most accurate as they contain the most detail, and are better corroborated by other sources. ${ }^{75}$ The apparent absence of quaestiones for a century could be seen as evidence that the earlier ones are retrojections and were in fact attempts by Livy to understand some earlier tradition of temporary courts using terminology he better understood. There is the additional problem that the ad hoc nature of the quaestiones, while acceptable when dealing with the Italian allies, would not have been tolerated by Roman citizens. We also have the problem that in the examples listed, all quasetiones were established by senatus consultum. While there is reference of the senate

a significant role in the narrative is because he was the ancestor of Fabius Pictor. This logic is used to identify at least one of Livy's source on the events of $331 \mathrm{BC}$.

${ }^{75}$ Neatly summarized in: Oakley 1998 597-8. 
(8.11.5-6), there is no explicit senatus consultum which appears to be standard procedure in the creation of quaestiones. Furthermore, it is unclear which magistrate headed the quaestio. Theodor Mommsen argued that it would have been a consul, ${ }^{76}$ though Richard Bauman counters by arguing that it is more likely to have been the aedile Q. Fabius Maximus. ${ }^{77}$ This said, all other quaestiones into veneficium were headed by praetors, and there are no attestations of any aedile heading a quaestio. Considering this incongruity and the others mentioned above, we can see signs of either editing by Livy's intermediaries or alterations by Livy himself to create an event with a narrative complexity and detailing that sits more comfortably with the quaestiones into veneficium and Bacchanalia Crises of the third and second centuries, which diminishes its value as a witness to the social milieu of the fourth century.

Despite rightly questioning the specifics of the trial, we have no reason to doubt any of the broader brushstrokes that came to characterise veneficium cases in Livy and that we discussed in the previous chapter. Here, the venenum is a material substance that could be consumed; it is also a fraus, a deceit or fraud, which certainly evokes its uncanny and incomprehensible nature. In these ways, this trail conforms to how we believe that veneficium was understood in its earliest sense. This trial also introduces a number of new components. A large scale investigation that, something akin to a quaestio, was impanelled to address the threat of veneficium to the Roman civitas and to process a large number of defendants. Finall, there is the issue of gender. The guilty parties and informer are explicitly women. The women in this narrative are deceptive free agents that would have continued if the were not exposed by the slave woman. In the narrative these women pose not just pose a direct dangerous threat to human life, but additionally to the Roman familial authority as it is their husbands and fathers that are being attacked. We should consider these broad strokes when we look at the other accounts of large scale veneficium as these attributes will come to colour

\footnotetext{
${ }^{76}$ Mommsen 1898143.

${ }^{77}$ Bauman 1974 255-58.
} 
the other incidents as they are seen in Livy.

Having considered this first instance of veneficium investigations in Rome, we should pause to mention the Bacchinalia Crises of $186 \mathrm{BC}$. The presence of veneficium in the Bacchinalia crises is a minor point, and one of the many crimes that were committed by the worshippers of this Bacchic cult. Regardless, its invocation by scholars when are also discussing quaestiones de veneficiis is surprisingly regular. ${ }^{78}$ The connection made by these scholars seems to stress an association of veneficium with religious deviancy and magic that the Lex Cornelia later covered and was discussed earlier. While this event does bear some similarities in regards to motifs with the quaestiones and will be touched upon on the following chapters, it has nothing directly to do with veneficium and we will move on.

Returning to the cases of veneficium, if we put the the relevant cases in chronological order there were three that occurred: a quaestio in 184, another quaestio in 180, and a final one in 152. The bulk of these trials occur over 25 years in the second quarter of the second century BC which suggests that something culturally and socially was changing in Rome that triggered the state to blame pestilence on venefici and systematically prosecute and execute them.

The next explicit instance of veneficium was two years after the Bacchinalia crisis. At the beginning of 184, the praetor Q. Naevius Matho was assigned the province of Sardinia to govern, but before taking his post he was required to investigate allegations of veneficium (Liv. 39.38.3). Livy goes on to tell us:

\section{Secundum comitia censorum consules praetoresque in provincias profecti praeter Q. Naevium, quem quattuor non minus menses, priusquam in Sardiniam iret, quaestiones veneficii, quarum magnam partem extra urbem per municipia conciliabulaque habuit, quia ita aptius visum erat, tenuerunt. Si Antiati Valerio}

\footnotetext{
${ }^{78}$ Gordon 1999 254-256; Kaufman 1932 157. A less explicit connection is implied by how Pharr structures his argument. Pharr 1931279.
} 
credere libet, ad duo milia hominum damnavit. Et L. Postumius praetor, cui Tarentum provincia evenerat, magnas pastorum coniurationes vindicavit, et reliquias Bacchanalium quaestionis cum cura exsecutus est. Multos, qui aut citati non adfuerant aut vades deseruerant, in ea regione Italiae latentes partim noxios iudicavit, partim comprehensos Romam ad senatum misit. (39.41.5-7) ${ }^{79}$

Over the following four months he condemned up to 2,000 people. Meanwhile, L. Postumius was separately tracking down a magnas pastorum coniurationes and some members of the Bacchic cults that had not been caught in the initial sweep in 186 BC. We are told that many of those who either failed to answer their summons or had fled were judged in absentia or eventually caught and prosecuted. While there are no records of the amount of people involved in all of the quaestiones that were simultaneously underway, clearly Naevius and his fellow magistrates were kept busy with the tasks at hand. Unfortunately, we do not learn what event occurred meant that a quaestio into veneficium was commissioned. The lack of any mention of an investigation inside of Rome suggests that was a response to something in Italy, which would explain its grouping here with the other quaestiones. ${ }^{80}$ Nonetheless it is worth noting the huge number of people that were affected and that there were apparently multiple comprehensive investigations being undertaken by praetors throughout Italy. This suggest that there was a persistent sense of unease in Roman Italy had apparently not subsidised with the repression of the Bacchanals.

\footnotetext{
79 "After the election of the censors the consuls and praetors departed for their provinces, with the exception of Quintus Naevius, who was detained for not less than four months before he could set out for Sardinia by the investigation of poisonings, a great part of which he conducted outside the City, in the municipalities and rural communities, because this method seemed more convenient. If one wishes to trust Valerius Antias, he condemned about two thousand persons. And Lucius Postumius the praetor, to whom the province of Tarentum had fallen, broke up large conspiracies of shepherds and diligently prosecuted what was left of the Bacchanalian investigation. Many who either had not appeared when summoned or had abandoned their sureties, hiding in that part of Italy, he pronounced guilty in some cases, and in others he arrested them and sent them to the senate in Rome." (ed. \& tr.) B. O. Foster 1919353.

${ }^{80}$ While this conclusion is gleaned from the absence of information it seems a logical step.
} 
The investigation of $180 \mathrm{BC}$ took place in a context reminiscent of that surrounding the murdering matronae of $331 \mathrm{BC}$. For three years Italy had been ravaged by plague and a prodigy was declared (Liv. 40.9. 3; 40.36.14). The praetor Ti. Minucius, and the consul, C. Calpurnius, both died as did many other leading men (40.37.1). ${ }^{81}$ At this point in his narrative, Livy introduces the thrust of the story:

fraudis quoque humanae insinuaverat, [se] suspicio animis, et veneficii questio ex senatus consulto ... C. Claudi praetori... C. Maenio ... decreta. ${ }^{82}$

It appears that the authorities, following the death of leading men, once again believed that veneficium was at work and a quaestio was commissioned. It is also important to note that the scope of the investigation was quite large. C. Claudius was put in charge of conducting it within Rome and the immediate surrounding area, while C. Manius was responsible for the territory beyond the ten-mile stone (40.37.4). Clearly, much like the other quaestiones, a wide net had been cast in pursuit of venefici. However, Quarta Hostilia, the wife of C. Calpurnius, is the sole guilty party identified in the affair. Livy points out that the death of the consul was particularly suspicious, although he preserves no evidence why Hostilia was accused beyond the rumour that Hostilia had promised to help her son, Q. Fulvius Flaccus, from an earlier marriage, attain the consulship as he had failed three times (40.37.6). The additional death of the other consul Piso was sufficient to exasperate the suspicious mood, and simply the allegation about Hostilia's promise was evidence enough in clearly paranoid times to result in her condemnation (40.37.7). Curiously, Fulvius Flaccus played no discernable role in the affair despite being the direct beneficiary of his mother's

\footnotetext{
${ }^{81}$ We might also assume that the "multique alii omnium ordium illustres viri" (40.37.1) referred to, at least in part, some of the large number of priests that died and need replacing during this year too (40.42.6-13).

82 "The suspicion of human treachery also suggested itself to people's minds and an inquiry into poisoning was assigned by decree of the senate to G. Claugius and G. Maenius." (40.37.4) 
alleged plan. ${ }^{83}$ It is on this note that we should consider this case in relation to our earlier one of the poisonous matronae. There the ancilla sought immunity before informing on her mistress. Clearly she felt vulnerable, but Flaccus felt no such risk to his career.

The motifs that appear in this case are familiar enough. Leading men of the state die against the backdrop of pestilence. The event was categorised as a fraus. A woman wass investigated and condemned. This story does contain some thematic innovations too. We find here only one person accused of wrong-doing. While Livy claims that she possessed the motive to kill her husband, there was no motive whatsoever for the murder of the praetor or any others. While we are left unaware of Hostilia's defence, we are left in no doubt that she was motived by ambition. This final innovation becomes commonplace, making frequent appearances in cases of veneficium during the late Republic and Empire. ${ }^{84}$

The quaestio of $180 \mathrm{BC}$ continued outside of the city though is only briefly mentioned in Livy. The praetor $\mathrm{C}$. Maenius was required to conduct a quaestiones de veneficiis ten miles outside Rome and beyond before setting out to Sardinia (40.43.2-3). We are given no further information except 3,000 people we condemned and that C. Maenius could have continued his investigations wanted to move to his province. The similarities between this quaestio and the previous one in 184, which resulted in 2,000 condemnations, are clear. Both were conducted by the praetor assigned to Sardinia. Both were investigations outside of the city of Rome. Both resulted in a huge number of convictions. In the case of this investigation, the comment by Maenius to the is worth noting to the effect that, if things were

\footnotetext{
${ }^{83} \mathrm{He}$ possibly went on to have served a particular harsh censorship in $174 \mathrm{BC}$ which included the removal of his brother from the senate (Liv. 41. 27.1). Though there appears to be some confusion whether this censorship was actually occupied by his cousin who was also called Q. Fulvius Flaccus and who served as consul in the following year. He fought successfully against the Ligurnians (40.44.3), and then prevented Transalpine Gauls from migrating into Italy (40.53.1-6). For these deeds he celebrated a triumph (40.59. 1-3). Additionally, he fulfilled a vow to pay for a temple and games for earlier victories in Spain (40.44.8-12; 45.6).

${ }^{84}$ Particularly in the imperial court where poisoning becomes the modus operandi of the emperors and their family. Drusus, son of the emperor Tiberius, was reportedly poisoned by his wife and Sejanus (Tac. Ann. 4. 8; Suet. Tib. 62), and Claudius by his wife Agrippina (Tact. Ann. 12. 66-7; Suet. Claud. 44.) and many more that are sadly beyond the scope of this thesis.
} 
not brought to a close, even more people would have been subject to investigation:

\section{Litterae adlatae, se iam tria milia hominum damnasse, et crescere sibi quaestionem} indiciis: aut eam sibi esse deserendam aut provinciam dimittendam. $(40.43 .3)^{85}$

It is not too difficult to see in these words a sense of diabolical synergy at play wherein informers, whether out a desire to settle old scores or fear, stepped forward in increasing numbers to provide information to the praetor. Given the importance of a single index in 331 $\mathrm{BC}$ with the matronae or a mere rumour Hostilia's guilt resulting in the execution, not just of them, but also of thousands in the subsequent investigations it is not hard to see how these investigations might rapidly have gained momentum.

One of the unique qualities of this quaestio is that it is the only one of our cases which provides details on the investigations lead by different praetors both inside and outside of Rome. In Rome only one person, Hostilia, is explicitly prosecuted for veneficium, while in the surrounding countryside Livy reports that 3000 people were executed. It is unlikely that Hostilia alone was prosecuted, not only because a quaestio was designed to process large numbers defendants, but also because we are told that investigations continue the following year with the newly elected praetor (40.44. 6.). A quaestio that spanned at least two years would have had more than one prosecution. While the omission of figures is curious, we might assume that the number of people prosecuted was at least smaller than than the number prosecuted by C. Maenius, for surely if there was a similarly dramatic number he would have communicated it to us. That said, the contrast remains. When considered alongside the similarly large number of prosecutions in $184 \mathrm{BC}$ we can see a trend wherein praetors were more fervent in their application of the law outside of Rome.

The final case is communicated to use in such a truncated form that it is nearly entirely unhelpful for our purposes. Yet, important details remain. It is preserved in the Periochae of

85 "A letter was received [by the senate] which said that he had already condemned three thousand people, and that the investigation was assuming greater proportions by reason of the evidence he received: he said that he would be compelled either to stop the investigation or give up his province." 
Livy and the Facta et Dicta Memorabilia of Valerius Maximus. According to the version preserved in the Periochae, in $154 \mathrm{BC}$ there was a de veneficiis quaesitum during which two matrons, Publilia and Licinia, were accused of having killing their husbands, both men of consular ranks. The case was brought before the praetor, testimony was given, and the matrons, by decision of their families, were executed (Liv. Per. 48). Valerius tells us that Publilia (in his version Publicia) was the wife of Postumius Albinus and Licinia was the wife of Claudius Asellus. He adds that their families opted to have them strangled, and that some people, convinced of their innocence, were willing to pay surety bonds for them (Val. Max. 6.3.8). From such a sparse and condensed stories, it is hard to discern more than the fact that two men of consular rank died and that their wives accused of plotting together to kill them. Although innocence was claimed, and believed by some, we do not know on what grounds either of these sides made their claims. It is worth noting the small number of people named, as was the case in 180 with Hostilia, though as a quaestio, we could presume others were too. Additionally, like the case with Hostilia and the original one in $331 \mathrm{BC}$, both are instances were women murdered their husbands.

Cato's view on women perhaps sheds some light on the story of Publilia and Licinia. According to him, and approvingly cited by Quintilian, nullam adulteram non eandem esse veneficam (Quint. Inst. 5.11.39). ${ }^{86}$ While Cato's distrust of women seems beyond doubt, one wonders what his basis was for this view. Whether or not women in his daily life were engaging in adultery is beside the point. Instead, if Cato's view prevailed at all, it represents a widely held assumption about why woman would poison, regardless of what someone accused adultery have said in their own defence. Thus, returning to the tale of Pubililia and Licinia, it would be hardly surprising if adultery had been the reason for keeping their transgressions in the family. Furthering the notion that adultery was in play is that Valerius Maximus offers this story as the third in his list of examples of women being handled in Rome's

\footnotetext{
86 "no adulteress is not at the same time a poisoner."
} 
glory days of the mid-second century (Val. Max. 6.3.9). The first example concerns that famous incident when the Horatius killed his sister who had become engage without his consent (V. Max. 6.3.7). The second example is related to the punishment of women found guilty of involvement in the Bacchinalia crises which were, inter alia, offensive to Roman sensibilities for their sexual license (Val. Max. 6.3.8). These women were also executed in their home by their family after rushed trials. The context suggests that their crimes were related to unsanctioned sexuality because, in the first example we see transferred loyalty to an extrafamilial male, and in the second a similar implication with the accusation of incesta (Val. Max. 6.3.9). Considering this, we see in this final quaestio a representation of one more important motif surrounding veneficium: adultery.

Having discussed these quaestiones de veneficiis we should consider the common themes and motifs that characterise these cases and how they fit with our understanding of veneficium that was established in the previous chapter.

Firstly, we see a purely poisonous understanding of veneficium in Livy's quaestiones that is evocative of an older understanding of the language. In our cases veneficium is always evil and does not require qualification. The venenum that is produced is a physical substance that, when consumed, brought about death. This was how it was understood in 331, 180, and 154. Though in the case of the trial of 331, the court room drama uses language akin to the legal arguments and interpretations of the Lex Cornelia de sicariis et veneficiis first attested to in first century $\mathrm{AD}$ but which likely existed earlier. Here the matrons claim that they were not creating poison but medicine. This appears to be very similar to the types of ambiguous arguments that we see in Quintilian in the first century. The court room setting for the majority of the narrative also further reinforces the notion that this was the inspiration of veneficium. We also certainly see no magical connotations with this depiction of veneficium. In these ways we can see that Livy is broadly conforming with an older understanding of veneficium and neither a magical nor ambiguous interpretations, though in the narrative 
details he uses more contemporaneous ideas.

Secondly, the declaration of fraus. As we argued earlier, poison operated on an uncanny level, effecting people in unseen and unknowing ways. It is difficult to determine when this idea of fraus specifically became attached to veneficium, but we are forced to acknowledge that Livy probably saw in veneficium a sense of deceit or trickery. In $331 \mathrm{BC}$ the attempts by the matrons to convince the magistrate that their poison was medicinal was labelled a fraus. We also see that in $180 \mathrm{BC}$ the entire affair of Quarta Hostilia is described as a such. Furthermore, we can also see the added deceit of women secretly revolting against their respective households and poisoning them.

Thirdly, only women are explicitly identified as veneficae. It is truly remarkable in Livy that women are the only named defendants that we encountered. Regardless, it seems unlikely that in 184 and 180 all of the apparently 5000 condemned people were women. Indeed, as we have discussed earlier, there existed a stereotype of the female venefica ${ }^{87}$ This seems to suggest that Livy was conforming with the gendered stereotype of veneficium that can be first attested to in the second century. While it is tempting to see in our quaestiones the origin of our stereotype we should note that Livy shifts to the masculine plural homines when describing those accused and damned in quaestiones in both 184 and 179 (39.41. 6; 43.2). Considering this and the sheer number of people accused it seems deeply unlikely that only women were prosecuted. Regardless, we can see Livy's motive in reporting the names of condemned women can be seen as a gesture affirming a gender stereotype of veneficium that existed in his own time, though also around the time of the quaestiones themselves.

Livy's depiction of these early investigations of veneficium also introduce a numberof other motifs which are unique to his quaestiones, such as pestilence being the true culprit. In 331, Livy clearly states that there was a plague in Rome, not to mention he personally suspected

\footnotetext{
${ }^{87}$ Quintilian says: latrocinium in viro, veneficium in femina credas "you would believe the charge of banditry with a man, and poisoning with a woman." (Quint. Inst. 5.10.25.).
} 
the plague that was responsible for the many deaths. We are also told by Livy that, prior to the quaestio in $180 \mathrm{BC}$, Italy had been struck by a terrible pestilence between 182-180 BC of such magnitude that the legion was unable to find sufficient recruits to be properly reinforced (40.37.14). Disease was surely exasperated by large scale urban migration caused by the Hannibalic War. Urban drift to Rome from Southern Italy and Etruria continued after the war, to the point that delegates from every community in Latinum were given an audience by the Senate in 187 to complain that huge numbers of their citizens had migrated to the capital and should be returned home (Liv. 39.3ff). All of this leads one to conclude that the cause of death for so many people in Rome and Italy in the first quarter of the century and in $331 \mathrm{BC}$ was most likely pestilence, and not mass poisoning by a coven of venificae.

Relatedly, we also see in our cases the common theme of prodigium. In $331 \mathrm{BC}$ the women are declared to have been driven mad and not acting out of a criminal intent. While in $180 \mathrm{BC}$, the pestilence that preceded the deaths was declared a prodigy. In both of these instances it remains unclear whether the plague itself was incorrectly declared prodigium or if these deaths provided smokescreen for veneficium. Prodigy was also commonly declared in relation to disease. There are multiple times in Livy where disease is recorded as a prodigy and there was no quaestio into veneficium (Liv. 4.21. 25, 5. 13. 4-8, 7. 2). We should assume then that when religious rites were proscribed by the priestly orders and the disease abated that it was presumed to have been resolved because of the rites. ${ }^{88}$ In this sense the priestly orders served a medical function by treating the cause of disease, a rupture of the pax deorum. The duoviri or the haruspices were the priestly colleges responsible for advising the appropriate action required by the priests, magistrates or people to remedy disturbance between the state and the gods. ${ }^{89}$ A cynical reading of the quaestiones might be that when the religious rites failed to produce any tangible results, the authorities focussed their attention elsewhere to resolve deaths and restore a sense of order.

\footnotetext{
${ }^{88}$ Jackson 1988 11-12.

${ }^{89}$ Beard, North, \& Price 1998 37-8.
} 
We also see in our quaestiones that they were undertaken both inside and outside of Rome. In 184 and 180, Livy explains that the investigations are being undertaken by different praetors have different urban and Italian jurisdictions. The details of all quaestiones is scant but the trend appears to be that those investigations outside of Rome yielded a significantly higher number of prosecutions than those within the city. This is perhaps because the ad hoc nature of the courts and trials established by a travelling praetor, afforded them greater power in the application of the law. This would explain why the recorded number of prosecuted people in Italy was so great compared to those in Rome. It has also been proposed that a quaestio headed by a magistrate possessing imperium, holding court over non-citizens with a very limited recourse to provocatio, meant that there was a greater likelihood of conviction. ${ }^{90}$ In these makeshift courts the magistrate controlled the trail and delivered the verdict himself, nor was he restricted to any of the regular procedural rules because the quaestio was a response to specific criminal action. ${ }^{91}$ It is perhaps then not surprising that the continued enfranchisement of Italian peoples alongside the establishment of quaestio perpetua which formalised the judicial process of quaestiones, ${ }^{92}$ saw a corresponding reduction in large scale veneficium investigations and prosecutions. This is all to say that, removed from Rome and armed with imperium, magistrates heading quaestio were more likely to prosecute disenfranchised Italians. Finally, when considering the unifying trends of Livy's veneficium investigations, we should note that they all occurred over a brief period of time. The majority of them happen over a 25 -year period of drastic socio-economic change in Rome. The closing years of third century and much of the second century was a period of drastic change for Rome and it is in this context that we can see the various quaestiones as an outburst of social anxiety and a response to a changing cultural environment. The annalist Lucius Piso dates to moral decline to the return of Manlius Volso's army from Asia bringing

\footnotetext{
${ }^{90}$ Gargola 2017 202-5.

${ }^{91}$ Lintott 1999157.

${ }^{92}$ Lintott 1999158.
} 
with them a great many luxuries items in 187 BC (Piso. Fr. 34p.). Other historians proposed different dates. Polybius detected a loosening in Roman behaviours after the fall of Macedon in 167 (Pol. 31.25.3), while Sallust presented the thesis that the fall of Carthage, by releasing Rome from the threat of their historic rival, led to a decline in moral standards (Sallust Jug 41f.). Livy appears to favour a synthesis of these events. It is in this context of drastic social change that we should consider the quaestiones investigating veneficium.

In summation, we can see through our analysis of the text that the depiction of venenfecium in Livy's quaestiones remains largely faithful to an older and traditional understanding of veneficium and its associated language. Veneficium refers solely to poisoning and does not possess any magical meaning. Considering this then we have no reason to doubt that the quaestiones in Livy occurred, nor do we have any reason to doubt that the matrons named in 331,180 , and 154 were prosecuted and executed upon having been found guilty of veneficium. Considering this then we can be assured in the relative accuracy of Livy and his assertions that he is presenting a truthful history. Though we can also see in his text is influenced by the connotations of veneficium in his own time. This is most clearly present in the courtroom drama and conflation of medicamentum with venenum in 331 , and the association of fraus to emphasis its surreptitiousness, and the belief that women were predisposed to poison. We also see additional themes that are solely seen in Livy's quaestiones. This includes the Livy's additional beliefs about Rome being in a state of moral decline also permeates his work and his discussion of the investigations of veneficium and it is through this lens that we can see finally why Livy might have chosen to emphasis the prevalent themes and motifs that we spoke of above. 


\section{Chapter Three: Veneficium Investigations as a Symptom of Social Anxiety}

Having considered how the trials of veneficium in Livy engages with our understanding of the terminolgy and identified key themes and trends in their depiction, we are now equipped to provide a potential hypothesis as to why they occurred. While we can be relatively certain the true cause of death was actually disease and not poison in our cases, we have not been able to explain why this pestilence resulted in the commissioning of quaestiones, especially during the second century. When we consider that these were all commissioned over a short period of time in the first part of the second century, this thesis posts that we should view them as a manifestation of social anxiety in reaction to a changing cultural environment. Rome and Italy in the final years of the third and throughout the second century was a drastically changing. The Hannibalic war changed the social structure of Italy and caused large scale urban migration and was responsible of the end of the small land holding peasants in favour of large, highly productive estates. While Roman conquests of the east also resulted in an influx of wealth and exoticism. When we consider some of the motifs of veneficium in Livy we see that these are also used by Livy to illustrate a perceived moral decline in Rome and, as such, may equate the two.

It has often been argued that Rome, throughout its history, was in a constant state of fear that foreign influences were corrupting Rome. ${ }^{93}$ Cicero begins book five of his De Re Publica, with a quote by Ennius, the father of Latin poetry: Moribus antiquis res stat Romana virisque (5.1). ${ }^{94}$ In many ways this sums up the popular belief that Roman supremacy over the Mediterranean was facilitated by viri, virtuous masculine and men, and by mores, morals and customs. This belief was ideological and representative of Roman national identity, not only explaining, but also justifying, Rome's supremacy. It is in this context that we should consider

\footnotetext{
${ }^{93}$ Indeed, Roman concerns about moral decline is a topic that has been spoken of in great deal by many scholars. See: Earl 1967; Lintott 1972 626-38; Edwards 1993.

94 "The Roman state is built on ancient traditions and on men."
} 
Livy's writing. Indeed his Ab Urbe Condita begins with the observation that:

Nulla umquam res publica nec maior nec snactior nec bonis exemplis ditior, nec in quam civitatem tam serae avaritia luxuriaque inmigraverint, nec ubi tants ac tam diu paupertati ac parsimoniae honos fuerit. Adeo quanto rerum minus, tanto minus cupiditatis erat; nuper divitiae avaritiam et abundantes voluptates desiderium per luxum atque libidinem pereundi perdendique omnia invexere. (1. $\operatorname{Pr.~} 11)^{95}$

While the text primarily conforms to the annalist tradition of recording events as they occurred annually, it also provides Livy with a means to educate his reader and provide lessons to them on how to turn away from the destructive agents of lust and luxury and return to a more modest lifestyle that facilitated Rome's early rise to power. By considering this reading and how it permeates Livy, we should consider this moralising tone whenever we consult Livy, and quaestiones are no different.

While ancient historians debated the beginning of Roman decline, it is generally agreed that Rome's moral decline begun in the decades after its triumph over Hannibal and was consolidated in the first quarter of the second century BC approximately at the same time that the number of investigations into veneficium gained momentum. ${ }^{96}$ For 15 years between 218 and 203, Italy served as the principle theatre of the Second Punic War with Hannibal's forces entrenched firmly in the southeast of Italy. Rome adopted a scorched-earth policy, wherein Roman allies were forced to destroy their crops, equipment, livestock, and farm buildings and retreat to local towns and cities (Liv. 22. 11. 4). Failure to do so would result in its

\footnotetext{
95 "No country has ever been greater or purer than our own, nor better endowed with noble precedents. Nor has any country managed for so long to keep itself free from avarice and luxury. Nowhere has the simple life of frugality been held in such honour until recently. For it is true that when men had fewer possessions, they were correspondingly modest in their desires. Recently riches have brought avarice and abundant pleasures the longing to carry luxury and lust to the point of personal ruin and universal destruction." Translation from: Edwards 199321.

${ }^{96}$ For a concise summation of the work on moral decline see: Edwards 1993 6-9.
} 
destruction by the Roman forces (Liv. 23. 32.14). While the effects that a scorched earth policy had on the production of food are debatable, ${ }^{97}$ the loss of a single years crop or farming equipment would have undoubtedly have been devastating for a subsistence farming family. Toynbee argued that a large number of people fled to urban centres and failed to return once the dangers had passed. ${ }^{98}$ It is understandable why these war refugees were unwilling to return home. In $206 \mathrm{BC}$, despite the best efforts of the state to convince them to return, the refugees refused to return home citing an inability to afford slaves, the loss of their livestock, and the destruction of their homes and farm buildings (Liv. 28. 11. 10-11). For the very poorest of farmers it would have impossible to rebuild without the starting capital for equipment and seeds. It is in these conditions then that we can understand the rapid rise of urban poor and the rapid growth in disenfranchised Italians in Roman settlements.

This war also saw resulted in the replacement of small landowning peasant farms with slave operated industrialised farming estates. The larger landowners were the only people with the capital reserves to recover from warfare. They also possessed more slave labour and could afford to hire season labourers from among the recently impoverished locals. Moreover, the shortage of food meant that the price of staple foods rose dramatically, with Polybius noting that the price of grain rose to 15 drachmae per Sicilian medimnus (Polyb. 9.11a), an incredibly high price. $^{99}$ The profitablity of farming in this environment incentivised larger landowners to increase their holdings, at a time when people were bring forced off their small farms in the south and war was causing substantial depopulation, the availability of cheap or abandoned land was an attractive and investment opportunity. ${ }^{100}$ Additional land was made available by the land confiscations in the south which was a punishment for cities who joined

\footnotetext{
${ }^{97}$ A.J. Toynbee in his monograph, Hannibal's Legacy, argues that the policy's effect was total and took decades to recover from. In: Toynbee 1965, $210 \mathrm{ff}$. In contrast, Brunt argues that any devastation caused by crop destruction was minimal and would only resulted in short-term hardship. See: Brunt $1971269 \mathrm{ff}$.

${ }^{98}$ Toynbee 1965332.

${ }^{99}$ Garnsey 1988192.

${ }^{100}$ Brunt 197126.
} 
with Hannibal. ${ }^{101}$ As Furthermore, as the army of Fabius advanced, 25,000 citizens of these secessionist cities were enslaved or executed for their betrayal (App. Pun. 134). This created an influx of cheap slave labour in Italy which, in addition to the seizing of territory and its conversion into Roman ager publicus, resulted in further investment opportunities by the capital rich landowners, which would not be resolved until the Gracchian reforms. ${ }^{102}$ In this case we see further evidence for the development of a trend that made it continuously harder for the small and respectable land holders to maintain their property with the rise of larger estates, equipped with slave labour, and devoted to commercial cash crops. ${ }^{103}$ By reviewing the Hannibalic War we see it was deeply impactful, changing the geographic distribution of the impoverished and their relationship to wealthy. The beginning of the end of the small landholding farmer, the development of large slave operated plantations, and the rapid rise of urban poor cause by economic migration from the Italic and Greek south and would characterise the second century. Having considered these facets, we should also consider how the concerns of urban migration and foreign influences became manifested in Roman life.

Increased Hellenization was a distinct concern of our moralist sources and characterised Roman culture in the Later Republic. While Rome had already become subject to Greek culture following their interactions with Magna Graecia, the second century saw a distinct rise in the contact between Rome and the various cultures of Eastern Mediterranean from military campaigning. These campaigns saw an influx of Greek and Asiatic goods, slaves, and practices, brought to Rome. This, paired with Roman aristocracy harbouring cultural ambitions which were funded by eastern conquests, resulted in all things Hellenic being particularly in vogue. ${ }^{104}$ Though while Greek art and culture was held in high esteem, the Greeks themselves were considered inferior. Romans represented themselves as morally

\footnotetext{
${ }^{101}$ Though this was unlikely to have been the only reason. One should also consider underlying tension between the Italian Allies and Rome, and that the presence of a large hostile force had taken residence at their doorstep.

${ }^{102}$ Cornell 1996110.

${ }^{103}$ Brunt 1971 352-53.

${ }^{104}$ Beard \& Crawford 1985 12-24.
} 
superior people who, unlike the Greeks, had a sense of self-control in the face of a seductive culture. This is probably best represented by Tacitus' depiction of Agricola who was tempted by Greek philosophy, but saved by his mother who taught him the virtue of moderation (Tac.Agr. 4). The corruptive opulence of Greek culture permeates the second century and can be seen in how our sources discussed. When we think of the themes of veneficium in Livy's early books we see the engaging with the fears of populace and exoticism in an increasingly metropolitan and cultural diverse Rome.

Finally, we should also consider the strained relation between Rome and its Italian allies in this period. Beyond the rise Italian migration to Rome, the Hannibalic War also changed Rome's relationship with its Italian allies. At the turn of the second century BC, Italy was inhabited by people that fit into three broad groups - citizens, Latins, and allies principally based on the polity to which they belonged. The groups were further muddied by the category of civitas sine suffragio that existed in some citizen communities, and the status of municipia in Italy. Prior to the second century Roman citizenship had been granted relatively freely in the Italian wars of the fourth and third century, but became increasingly uncommon in the second century in response to Roman dominance of the Mediterranean and the increasingly legal and financial benefits that citizenship held in a Roman world. ${ }^{105}$ Rome was beginning to treat its allies as subordinates. ${ }^{106}$ Italians were increasingly living with and like Romans but lacked the same rights. These tensions would continue to escalate until the Social Wars were eventually drawn to a close and the Lex Julia made most of Italy holders of Roman citizenship rights. ${ }^{107}$

The perception of social anxiety and moral decline are further reinforced by Livy's

\footnotetext{
${ }^{105}$ Discussion of this at large is beyond the scope of this thesis. For more detail see: Keaveney 1987 3- 39.

${ }^{106}$ Readily seen in the consul Q. Fabius Labeo in 183 BC while negotiating a boundary dispute between Naples and Nola, mislead both and claimed the territory between them as ager publicus (Cicero, De Officiis, 1.33), and the demands of the consul L. Postumius in 173 BC that his stay in Praeneste should be lavish and paid for by the city due to his personal dislike of the people (Liv. 42.1.6-12).

${ }^{107}$ Gargola 2017 88-91.
} 
placement of prodigium. A prodigium was an indication that something was seriously wrong with the pax deorum and, as such, an immediate response was required. These wrong actions were always the fault of the Romans, and later their allies. Once accepted, it was referred to either the duoviri or the haruspices for advice on the appropriate action that was required by the priests, magistrates or people to remedy disturbance between the state and the gods. ${ }^{108}$ Most prodigies were resolved with either a ritual destruction or removal, ${ }^{109}$ or the restoration of sacred borders. ${ }^{110}$ Prodigies peaked at times of grave danger to the city. ${ }^{111}$ This is best illustrated with the huge number of prodigies being recorded during the Hannibalic war, including twelve in 218 alone (Liv. 21.62). ${ }^{112}$ In these instances, we can argue that the declaration of a prodigy correlates to times of stress. It is with this in mind that we should also note that, while the number of prodigies declined after the war, the number outside of Italy increased over the following decades. The timing of this may suggest that Roman concerns were shifting to maintaining unity in the Italian peninsula and the increasingly ethnically diverse population of Rome. ${ }^{113}$ It is in this context that we might consider the

\footnotetext{
${ }^{108}$ Beard, North \& Price 1998 37-9.
}

${ }^{109}$ Examples of this include a peculiar scapegoat ritual, where in 101 priest lit the horns of a goat on fire and paraded it through the city before expelling it through one of the cities the gate (Obsequens 44A), and the live burial of two unchaste vestal virgins in the walls of the porta Ocllina (Livy. 22.57.2).

${ }^{110}$ This would include the lustrio, a priestly procession around the city to establish its sacred boundary (Liv. 35. 9. 5. \& 42.20. 2). We can also see this in the supplications of entire populations offering sacrifice at temples to restore the boundary between the gods and mortals. A grand example of ths is the supplications after the defeat at Lake Trasimene (Livy. 22.10.9). For a greater breakdown of this see: (ed.) Rosenberger 2007 292-7; Gargola 2017 99-105.

${ }^{111}$ For more on Livy's attitude and principle for selecting prodigy to describe, see: Levene 1993, 1737. Here he also argues that Livy using prodigies as a literary device, placing them in his narrative during dramatic events, to heighten the tension or to evoke a dangerous atmosphere. This said, we should note that Livy's lists are sparse and factual, and, in fact, they are noticeably not elaborated into the horror stories that they could have been. It certainly remains possible that Livy incorporated material on prodigies from earlier sources even if, as Levene convincingly argues, their placement was manipulated. For more on the origin of Livy's prodigy material see: North 1986, 255.

112 Though perhaps the most famous of this was the rituals performed after the Roman defeat at Lake Trasimene in the second Punic war which saw the sacrifice of 300 oxen, games costing 333,333 asses, and religious processions requiring participation of all inhabitants of Rome (Liv. 21. 9-10).

${ }^{113}$ Orlin 2010 131-3. 
increase in prodigia to be more than simply the state's attempt to explain an unusual event and restore order to a fearful populace, but an indicator of Roman concern for the balance of power in Italy during this period. Considering this when we read about the events of $180 \mathrm{BC}$ we can see that Livy is using the language of divine dissatisfaction to communicate societal strain. The declaration of a prodigy due to ongoing pestilence throughout Italy and the attempts by the Rome to remedy it occurred during a period where the relationship between Rome and Italy was strained. When this appears to have failed a quaestio is sent to resolve suspected poisonings. Considering this we can see the pairing of prodigia with veneficium, in $180 \mathrm{BC}$, should therefore be considered as an indicator in Livy of social pressure and stress.

On the topic of prodigia, we should consider why in other instances when disease was declared by a prodigy they were not followed by accusations of veneficium. We see disease declared a prodigy throughout Livy (Liv. 4.21. 25, 5. 13. 4-8, 7. 2). In these instances, the religious rites were performed and believed to have been remedied. While the immediate assumption one might have is, that in these instances the observation of religious rites coincidently coincided with the disease abating and a quaestiones was only commissioned when they failed. In this context, it was only after the failure of the traditional methods of resolving plague failed that the state begun to investigate individuals. By identifying a scapegoat, the state apparatus could illustrate that they were fulfilling their roles as protecting the people and ensuring the good and proper relationship with the gods. However, there are multiple occasions where the event that was declared a prodigy continued or reoccurred after the rituals had been completed. ${ }^{114}$ In lieu of this we might consider that the quaestiones investigating veneficium were a unique response resulting from a specific set of circumstances rather than a de facto response to the presence of disease.

\footnotetext{
114 Two examples include, following reports of earthquakes in $193 \mathrm{BC}$, the Senate declared that on any day an earthquake occurred no other reports of earthquakes should be made except the first one (Liv. 34.55.4). This would have presumably have helped them deal with processing multiple reports of the same earthquake and any aftershocks. When a plague of locust ravaged Apulia in $172 \mathrm{BC}$, a prodigy was declared and rites were performed.
} 
In addition to the pestilence being a prodigy, we often see its paired with veneficium by Livy and possessing and entrenched relationship with metropolitanism and lifestyle. Roman disease was largely understood in terms of bad air and the body's ability to resist it. Lucretius, writing in the first century BC, explains in his De Rerum Natura, disease is spread through seeds that float and corrupt the air around them. When the corruption has concentrated enough, and the soil is damp, it will sink and coalesce at ground level in a mist or fog, it is because of this that marshes were considered such dangerous and sickly places (VI. 1090-1102). Disease in this form can land on and contaminate food and water, or inhaled (VI. 1125-1137). This explains how damp and wet climates, were more susceptible to diseases (VI. 1103-1118). ${ }^{115}$ It is in this context that we see the logic behind ancient beliefs about why cities were unhealthy and prone to disease. ${ }^{116}$ When it comes to pestilence, the ancients are guilty of conflating correlation for causation. Indeed, bacteria and viruses flourish in places that typically odious, and Rome was such a place. This was principally caused by poor sewerage and drainage, communal bathing, malnutrition, and high population density further exasperated by the mass urban migration of the second century. ${ }^{117}$ As discussed earlier, the population of Rome grew rapidly as a result of the Hannibalic and its importance as a capital of a world power. ${ }^{118} \mathrm{With}$ the influx of impoverished Italians we should not be surprised then that Rome saw a correlating rise in disease.

It was generally believed the best form of medicine was preventative and achieved by proper maintenance of one's body through diet and exercise. Cornelius Celsus noted that disease was traditionally found in cities because they are home to "the weak" whom he identifies as urbanites and scholars (Celsus, Med. 1.2). The way to avoid illness was for a

\footnotetext{
${ }^{115}$ The association of epidemics with air and climate was not a Roman invention but one that can be traced to the Hippocratic treatises, perhaps most clearly found in Regimen II's climatological chapters, wherein disease resulted from the interaction of people with the environment (2.37-8). For a Hippocratic focus see: Kosak 2000 35-54.

116 (Diog. Laert. 8.70), Galen, On Good and Bad Juices 9, 6.795K; Commentary on Hippocrates' Epidemics 6.4.10: 17B $159 \mathrm{~K}$ ).

${ }^{117}$ Nutton 2000 67-70.

${ }^{118}$ Toynbee 1965 332-340.
} 
man to eat healthily, regularly exercise, live in a warm and dry climate, and avoid the city (Celsus, Med. 1.1). There are clear class implication in Celsus: the best way to fight disease is to be an aristocratic man that allowed for an alternative country homestead, a balanced diet, and regular exercise. Relatedly, earlier in his prooemium, Celsus explains that many of his theories are Greek in origin, though this was because it was in Greece that indolence and luxury began to wreak havoc in the community (1. Pr. 2-5). It is in this vein that Pliny explained how, during his own lifetime, diseases were being spread among the elite by the adoption of foreign gluttonous behaviour which seemed to be transferred by upper-class men when they kissed one another replicating foreign, and a deeply un-Roman, practice (Pliny. NH. 26 1-3). Illness therefore is largely explained on the basis of an individual's interaction with the surrounding air. However, the ancient author might define or qualify it, this receptivity and resistance, either strengthened or weakened by lifestyle, was crucial in determining the the body would response to bad or unaccustomed air. Considering then the moralising tones of Livy we might argue then that his attestation of disease may be intentionally evoking a disdain of metropolitanism and foreign excess that flourished in the second century.

The increased popularity of Greek medicine also begun to threaten the institution of the paterfamilias. According to Pliny the first formal medicus to arrive at Rome was the surgeon Archagathus in 219 BC. He was granted citizenship and a place outside the city to establish his practice. This enthusiasm was short-lived as the people came to learn that he specialized in cautery and surgery, earning him the nickname Carnifex or "Butcher." Achagathus' reputation was such that Pliny tells us that he alone was the reason Romans developed a lasting distrust of artem omnisque medicos (P1. NH. 29. 12-12). ${ }^{119}$ Moreover, these medici were outsiders in the utmost sense, being firstly, non-citizens, and secondly largely slaves or former slaves. The threat under consideration here is how their medical practices directly contradicted and challenged the central pillar of the Roman household, the paterfamilias. By tradition, the

\footnotetext{
${ }^{119}$ We should note that anti-medical sentiments were not exclusively Roman, and were in fact also shared by the Greeks. See: Kudlien 1970 99ff.
} 
paterfamilias was completely responsible for the well being of his famila. This included a duty personally to provide medical care to his charges, in essence, this tradition is represented in Cato's De Agricultura, Varro's De Re Rustica, and Pliny's Naturalis Historia. These encyclopaedic reveal a base of medical knowledge necessary for the day-to-day maintenance of the famila at the hands of the paterfamilias. Cato, Varro, and Pliny were wealthy landowners. Their texts exemplify the Roman intellectual ideal of the self-sufficient paterfamilias, a man of wide learning and with a practical outlook. By observation, experience, and reading Roman elite felt that they could master the art of medicine without formal training, just as they mastered the techniques of agriculture, or the methods of civilian and military administration, and the management of a large estate work-force. ${ }^{120}$ The tradition medicinal methods, best seen in Cato's beliefs regarding cabbage and Varro's beliefs in the powers of fasting and chanting, ${ }^{121}$ and the Roman traditions they represented, were effectively at odds with the newly arrived professional doctors belonging to the lower classes but challenged the authority of the paterfamilias. The arrival and popularisation of the medici in the second century is therefore further evidence of the wider development of Hellenisation in this period and threatening role it played to Roman institutions.

Livy intended for his work to illustrate and reflect the glory of ancient Rome in contrast to the decline which resulted in the fall of the Republic, it is within this narrative that the regular appearance of women in the quaestiones into veneficium should be considered. Women play a large part in early Livy but are noticeable absence later in the text. In all twenty-one passages where women are specifically mentioned by name, nine occur within the Livy's first two books,

\footnotetext{
${ }^{120}$ There were practical reasons to be versed in medicine: to ensure a healthy slave work force. Nutton 2004 162-4.

${ }^{121}$ Cato views cabbage as a panacea. When consumed it can alleviate constipation, hangovers, and nausea (Cato, Agr. CLVI), applied externally as a poultice to treat ulcers, infected wounds, tumours (CLVII). More in keeping with folk traditions is Cato's insistence that the use of charms could cure any kind of dislocation (CLX). Similarly, Varro, in his own De Agricola, explained to his reader that foot pain could be cured by fasting and chanting invocations for the ground to swallow the pain (Varro, Rust. I. 2. 25-8).
} 
while they are only mentioned five times in the remaining 35 extant books. ${ }^{122}$ These are the books where we see the famous depictions of Veturia, Cloelia, Lucretia and Virginia. ${ }^{123}$ However, regardless of the virtues that they possess, all of them are differential to men and enable or prompt them to accomplish great things. More often women are considered vain or greedy. Perhaps, famously Tarpeia who betrayed Rome for the promise of jewellery (1.2.6-9), and Tullia the wife of Lucius Tarquinius, with insatiable ambition saw her plot to murder her father (1.46-59). Considering Livy's depiction of the most famous women from Rome's early history we see on his display a belief that good women are those that, even when taking an active role, are enablers of great deeds in men. In contrast, women who are proactive are ambitious, greedy, or indulgent, a point that is illustrated in that they typically kill male family members. When considering the named characters in Livy's investigations veneficium we see they broadly conform with the trend. In $331 \mathrm{BC}$ the Matrons murdered their husbands and fathers, but do so because of madness and not criminal intent, stripping them of agency, while in 180 BC Quarta Hostilia, motivated by ambition, murdered her husband to promote her son to higher office.

Livy's concerns regarding luxury in relation to women is also displayed in his discussion of Cato's speech on the Lex Oppia (34.1.1 - 34. 5. 18). The Oppian sumptuary law targeted the acquisition of wealth and its exhibition by women and put in place during the Hannibalic war. While the law was under consideration for repeal in 195 BC, women were lobbying their husbands and the magistrates, though the consul Cato firmly spoke in its favour (34. 1. 6-7). While it is difficult to assume that Livy wholly agreed with Cato, his disapproval of the women public lobbying implies that he believed in principle with Cato's disapproval of

\footnotetext{
${ }^{122}$ Smethurst 195080.

${ }^{123}$ Veturia is praiseworthy because she convinces her son Corialanus to remember his duty and end his treasonous war against Rome (Liv. 2. 40. 5-9). Cloelia's escape from the Clusium camp is not as praiseworthy as her later decision upon being returned to return the young Roman boys. (2.13.6). Lucretia's rape and suicide in Livy is what pushes Brutus to oust the kings and establish a republic (1.59.1) The only importance of Virginia is that her death brings into clear relief the tyranny of Appius (3. 44-8).
} 
the repeal of this law (34. 1. 1-5). The crux of Cato's argument is that any relaxation of moral and social standards in regards to women will result in in the inevitable decline of Rome. Women, by their inherent nature, are more susceptible to luxury and greed, and as such, might be the entry point for such vices (34. 4. 15-16). Furthermore, Livy's decision to place the debate at the beginning of book 34, instead of at the end the end of book 33, might be interpreted as a symbolic gesture which marks the beginning of Roman decline with its continued conquests in the East. ${ }^{124}$ Regardless of this, we see in Livy's discussion of the Lex Oppia another example of his belief that women were susceptible to luxury and vice, considering this and its date shortly before the quasetiones we should consider them as a further indicator of moral decline.

When considering the investigations into veneficium we can see that the majority of these quaestiones were clustered in a short period during a time when Rome and Italy were undergoing extensive changes to their social and political structures. These included the end of the Hannibalic War, which resulted in extensive urban migration and the end of the independent peasant farmer, the Hellenization of elite culture due to increased exposure to Greece and the East in the second century, and the continued deterioration of relations between Rome and the Italian allies that eventually resulted tin the Social Wars. This thesis posits that when we consider some of the accompanying motifs of veneficium, then we can see in the moralising Livy, the spate of investigations is one of several indicators that Rome was, from his perspective, in a state of moral decline. This suggests in turn that the quaestiones de veneficiis were in fact a violent reaction to social and cultural changes in Rome during the second century.

\footnotetext{
${ }^{124}$ So is argued by: Smethurst 195084.
} 


\section{Chapter Four: Interdisciplinary Interpretations of Veneficium}

Having investigated the quaestiones into veneficium in Livy, one can argue that the massive investigations that resulted thousands of executions were the result of increased social pressure due to the perceived loss of cultural practices and traditions due to urban migration and the popularisation of eastern culture. While this may appear to be a post hoc argument, we find that when we engage with some of the theories and methods used in sociology and anthropology a clear connection between social anxiety and violent persecutions. While scholars tacitly hint at Livy's veneficium trials as witch-hunts any real academic backing to these implications is lacking. Anthropologically speaking, Witch-hunts, or witch-crazes, are local outbreaks of witch-hunting that give the impression that the community has become obsessed with a fear of perceived group. They are the result of a collision of inherent social fears. Before any such study can go underway we should clarify that anthropology and sociology exist in entirely different schools with distinct focuses. Anthropology is rooted in the study in human culture, while sociology is the study of societies. Anthropological understandings of witches are important, but not necessary for a witch hunt. Modern secular examples include Stalin's search and purge of Trotskyites in the 1930's Soviet Union, and the United States Senator McCarthy's investigations into potential communists during the Second Red Scare. ${ }^{125}$ In these instances, concepts such as moral panic, mass hysteria, and scapegoating are more important. This final chapter aims to review these facets and illustrate the ways that adopting interdisciplinary tactics allow us to better understand and interpret Livy's quaestiones.

We must first consider what, from an anthropological perspective is meant by Witchcraft and Witches. As Maxwell Teitel-Paule drew attention to in a 2014 article, Latin is rich in words describing people who might be described as witches. A witch might be a cantrix,

\footnotetext{
${ }^{125}$ Sanders 19958.
} 
scaerdos, vates, saga, maga, malifica or a striga. However conversely, the English word 'witch' lacks specificity and can be used to describe any person, typically a women, that possesses magical powers. ${ }^{126}$ This definition is inadequate in anthropology. Generally speaking, witchcraft is the expression of a malign power which exists within a person's body, while sorcery is the specific use of a magical craft or knowledge to harm or benefit other people. ${ }^{127}$ While this may seem neat and tidy, reality and case studies illustrate that any given society will only generally adhere to these categorizations and will inevitably defy them in some way. The original legislation that facilitated the witch-hunts in Europe conflated people who created charms, healers, people who cast curses, and also those who protected against curses. All such people were considered outside of the church and state's control and therefore subversive. ${ }^{128}$ We also see that in some societies a witch might not have the ability to manage their magical abilities, which results in some cultures adopting cleansing rituals that do not result in death. Considering these circumstances we see that it is not worthwhile making and adhering to any strictly defined distinctions and instead should recognise the complex and shifting boundaries that witchcraft and sorcery occupy in any culture's conceptualisation. ${ }^{129}$

Indeed, it is with this mind set that we should approach witches. Inconsistencies across different cultures are irrelevant, since societies are concerned with individual given cases and not with constructing a general scheme of thought. ${ }^{130}$ As Lambek notes, explanations of misfortune "are not particular manifestations of closed, self-affirming systems of thought, but... they are rather provisional and contestable readings of events, moments in the life of narrative." $" 131$ Nor does one such reading necessarily preclude another in the course of the search for causes and accountability. Indeed, a witch is never the only explanation for misfortune. Among others might be the believed anger of the ancestral spirits or malevolent

\footnotetext{
${ }^{126}$ Paule 2014745.

${ }^{127}$ Stewart \& Strathern 2004 1-2.

${ }^{128}$ Stewart \& Strathern 2004 3-4.

${ }^{129}$ Stewart \& Strathern 20045.

${ }^{130}$ Lambek 1993 17; referring to Evans-Pritchard 1937 40-1.

${ }^{131}$ Evans-Pritchard 1937385.
} 
ghosts, ${ }^{132}$ and people often consider a variety of alternative explanations before blaming witchcraft. ${ }^{133}$ In short, different circumstances could produce different explanations, and different parties might attribute different causes to the same event. In England during the sixteenth and seventeenth centuries, the family of a deceased person was more likely to accuse a neighbour or friend of witchcraft than other people in their community who did not intimately the deceased. Additionally, it was more common for relatives to make their suspicions known when the accused already had a reputation for witchcraft. Otherwise, knowing that they might not be believed suspicions might shift to them. ${ }^{134}$ It is on this grounds that because of these that we do not see people everywhere constantly accusing one another of witchcraft.

We should turn to what characterises the witch in anthropology. As the root cause of misfortune, the witch is a personification of evil. Witches contravene all basic values of society. They engage in the worst kinds of antisocial behaviour, offending against the most deeply held cultural mores. Consequently, they are often believed to indulge in taboo practices, particularly types of sexual activity, such as incest, bestiality, and necrophilia. Frequently that are believed to kill members in their own families, the people to whom they have the strongest obligations, for selfish ends. Witches may also indulge in cannibalism, either physically or of the soul. Their actions governed are by hatred, and envy to such a degree that they will kill or cause harm simply out of malice or seemingly at random. They are often associated with what a culture identifies as evil or suspect in some way. They operate at night, often with animals, or familiars, that are also related to the night or evil. They may also be associated in a place spatially considered dangerous or evil. That is to say they reside and carry out their nefarious actions in the forests, removed from or on the fringe of settlements, marking them as

\footnotetext{
${ }^{132}$ Mair 1969 11-4.

${ }^{133}$ Macfarlane 1970108.

${ }^{134}$ Macfarlane 1970108.
} 
outsiders. $^{135}$

While what an individual culture or society describe as a 'witch' may not conform to all of the tropes and motifs listed above they may be associated with many of them. The Shona, a group of people found principally in Zimbabwe and neighbouring countries, believe a witch is always a woman, jealous, revels in their evil, and possesses an insatiable desire to kill. She may attack people at random and may target members of her own family. The Shona witch may congregate with fellow witches at active at night and command owls and snakes to bewitch their victims. Witches are believed to exhume bodies and cannibalise corpses, while also using parts as ingredients in dark "medicines." 136 This is similar to the beliefs of the Tanggu, an ethnic group in Northern New Guinea. In this case the word ranguma is used, though it may be translated as 'sorcerer,' 'witch,' 'assassin,' 'non-conformist,' or simply 'unusual.'137 The ranguma lives in the forests on the fringes of the community, they are described as possessing an unusually proportioned body, being surly and unsociable, and willing sell their magical services to cause illness or death in others. However, the ranguma is always a man, does not congregate with his peers, and has no association with animals. ${ }^{138}$ The association of animals and witches is much more entrenched in the post- medieval English witch accusations and is a vital part of English folk concepts of witchcraft. ${ }^{139}$ These familiars were often believed to be suckled by the witch, who is violating laws of nature by substituting a young child with an animal. The English witch was normally accused of killing or causing farm animals to go lame, and of prolonged death and illness. ${ }^{140}$ Macfarlane's study of witch accusations in Essex found that human death was the single largest witchcraft offence,

\footnotetext{
${ }^{135}$ Mair 196915.

${ }^{136}$ Crawford 1967 111-27; Gelford 1967 11-31.

${ }^{137}$ Burridge 1965230.

${ }^{138}$ Burridge 1965 230-1.

${ }^{139}$ Macfarlane 1970 6. Additionally, for more about how familiars were an earlier folk tradition adapted by the the Sixteenth century clergy into concepts of satanic rituals see: Holmes $199345-$ $78,65-75$.

${ }^{140}$ Sanders 1995 33-4.
} 
making up approximately 40 per cent of witchcraft accusations. ${ }^{141}$ We should also consider the gender balance of those accused. Of the 270 suspected witches tried at the Essex Assizes between 1560 and $1680 \mathrm{AD}$, eight per cent were men. ${ }^{142}$ The number of men accused and prosecuted elsewhere, though, was higher in the Great Witch Craze of the late Sixteenth and Seventeenth centuries AD. In Scotland, south-western Germany, Venice, and the Jura region on the Franco-Swiss border, approximately 20 per cent of the accused were men. ${ }^{143}$

Having considered how the witch was perceived in the cultures where they are prevalent, we should now turn our attention to why they might share these key characteristics and motifs. Anthropologists who lean towards functionalist approaches, believing that every feature of society serves an innate purpose and reason, have argued that anti-sociality is the root cause of witchcraft accusations and that witchcraft sanctions a code of moral conduct. By accusing person of witchcraft and of having violated the accepted moral values of a given culture, the accused is forced to re-join society. In this way, witchcraft can be seen to serve functionally as force of conformity. Not only might one be accused and therefore pressured to conform, but additionally the fear of behaving unsociably towards a witch with the power to cause misfortune would have provided additional incentives to be sociable. ${ }^{144}$

We should also consider the witch as rooted in social structure. As discussed earlier, the witch is often depicted as living and practicing outside of a settlement. One category of people often accused of witchcraft is strangers and foreigners. Paul Baxter's analysis of witchcraft among nine east African pastoral communities showed that several of them almost exclusively blamed disease and misfortune on the witchcraft performed by recent immigrants and their descendants. ${ }^{145}$ An additional commonly evoked category, similar to the previous one, is of the ambiguous and marginal person who exists as simultaneously both insider and

\footnotetext{
${ }^{141}$ Macfarlane 1970152.

${ }^{142}$ Thomas 1973620.

${ }^{143}$ Sanders 1995 181-2.

${ }^{144}$ Gluckamn 1959 86. For an argument regarding how English witches might pretend to good neighbours in an attempt to disguise their antisocial core see: Macfarlane 1970172.

${ }^{145}$ Baxter 1972 165-9.
} 
outsider. They are perceived as a part of one group while also having allegiances to another resulting in perceived conflicting loyalties. As such they are susceptible to accusations of being 'the enemy within.' This is classic witchcraft language, and their presumed treachery may be believed to take the form of witchcraft directed into inside the group in which they reside. ${ }^{146}$ In Baxter's field work, he describes some of the immigrant groups as ambiguous, especially those that have joined communities from the same ethnic group but with slightly different cultural traditions. These groups are more prone to be accused of witchcraft. ${ }^{147}$ The principal example of this is women marrying into Zulu groups. These women marry into separate local groups or different clans, thus making them new and a part of a new kin group while also maintaining their strong blood ties to the family they were born into. It is not surprising then that married women alone are accused of witchcraft in Zulu culture. ${ }^{148}$

Because of the widespread tendency for women to be accused of witchcraft more commonly than men, Gluckman has suggested that there is a deeper, more basic ambiguity in the position of women. They bear children, which ensures the continuity of the community and therefore influences its power and social standing. However, when these children grow up, they compete for power, property and social position, and therefore create conflict and dissension. Consequently, women introduce conflicting social processes into a community. That this is the cause of the prevalence of women witches is difficult to prove. However, the fundamental ambiguity in the social status of women in many societies is shown by the fact that in many cultures women are considered intrinsically inferior, weaker, and more capable of evil by their inherent nature. ${ }^{149}$ Indeed this is a significant point. The majority of patriarchal societies hold the belief that women are more susceptible to, and capable, of evil. This may happen through inculcation of evil spirits, either unwittingly or by seduction, or simply through an inability to

\footnotetext{
146 Sanders 199594.

${ }^{147}$ Baxter 1972163.

148 Gluckamn 1959 98-100.

149 Gluckman 1965 224-7.
} 
suppress the ever present and inherent evil that women possess. ${ }^{150}$

In many cultures the position of the elderly is an ambiguous one. Most cultures treat the elderly with veneration, typically due to the wisdom that they have accrued. However, in reality their age may make them a nuisance and a drain on society. Their ambiguous position arises from the fact that while they are members of a community and share in its benefits, they are limited in their ability to contribute to it. Likewise, as with to women more generally, they have to compete with their children for social positions and power in a community. Considering the association of elderly with knowledge, and the fact they were social drains reliant on others, it is not surprising that they were vilified and transformed into witches. ${ }^{151}$

A consideration that we should also consider is self-confession. So far we have discussed those identified as witches principally as scapegoats, a persecuted group that is subject to state power and yet we should also consider self-confession and mass hysteria. The theory of self-confession contends that in some cultures, individuals might acknowledge their powers and abilities, this in turn opens them to persecution. These figures might be witch doctors, conjurers, white witches, or cunning folk, depending on the culture. ${ }^{152}$ These selfdescribed magic users existed on the fringe of society and whose services were used as a last resort. However, their status as an outsider is also what means that these professionals can easily become victims of persecution. Ioan Lewis posits though that the confessions of women to be witches allows women who aresocially inferior and lack the same social protections as men, to elevate themselves in the eyes of a community by possessing special powers and therefore insuring their own safety. The safety that the threat of magical misfortune is only overcome when the community bands together to accuse the witch. ${ }^{153}$ In this way selfconfession functional serves to empower and protect an individual, while simultaneously supporting group cohesion.

\footnotetext{
${ }^{150}$ Gluckman 1965 224-7.

${ }^{151}$ Crawford 196781.

152 Thomas 1973 210; Sanders, 1995 61-4.

${ }^{153}$ Lewis 1986 51-62.
} 
Considering these definitions of witches and witchcraft we are now equipped to consider if the venefica was a witch in an anthropological sense. As discussed in chapter two, there are several motifs and characteristics that surrounds how the Romans, and Livy in particular, understood the witch. All of the named venefeciae are accused of having murdered their male family members, wither their fathers or husbands. This is implied in the case of the matrons in 331, where the two leaders of the matrons are specifically patricians suggesting that the leading men of the city that had perished were their relatives, and the medicine they claimed to be making for their sick family was in fact intended for them (Liv. 8.18.8). The connection to violent acts against their kin group is much clearer in the examples of Hostlia, Publilia and Licinia who all were executed for having killed their husbands by poisons, were accused of having killing their husbands, both men of consular ranks (Liv. 40.37.6; Per. 48). All named veneficae are women, though this gendered language shifts when discussing the prosecuted people in 184 and 179 where they are simply identified as people, homines (LIv. 39.41;40.43). Though the seemingly random acts of violence acts are not clear elsewhere in Livy.

The named veneficae in Livy's named matrons of senatorial status, marking them out as elite. In the account of the trial in $331 \mathrm{BC}$, all the accused were matrons, which does not necessarily indicate that they belonged to the social elite but does suggest an air of respectability. This is problematic for the anthropological understanding of witches, as they typically represent the lowest members of society or those who reside on its fringe. The Roman matron was a central pillar of the roman conception of the household and was one that existed very much inside of society. This is not to say that when the quaestiones broke out that they were they were not prosecuted. In fact, we have no reason to doubt that women and matrons may have been included in those prosecuted for veneficium, especially when we consider the quote attested to Cato in the second century (Quint. Inst. 5.11.39) that women were natural veneficae would imply that there was a good chance that they were prosecuted. It seems unlikely though that only respectably matronae were accused when the praetors took 
their investigations into the countryside, but difficult to concretely prove. What we can say with some degree of certainty that, considering the thousands of people prosecuted, and the reduced burden of proof required in the ad hoc cases held by the investigating praetor, that many of those identified as veneficae were of the lower classes.

Additionally, we do not know the age of the veneficae in Livy. Roman marriage practices being as they were means that we are left unsure of the age of the matronae. The exception to this is Quarta Hostilia who we know was an older woman but was by no means elderly. While age qualifications had not become a codified facet of the cursus honorum in the second century we know that her son and husband must have been of a similar age and as such she may have been in her 40's. ${ }^{154}$ Considering these qualities of Livy's veneficae it is hard to see them totally fitting into the mould we have created of a witch.

Married women in Rome do however exist in a similarly ambiguously as she is simultaneously both an insider and outsider. In patriarchal Rome, the act of marriage effectively saw the bride transform from a father's daughter into a husband's wife, symbolically transferring between households. Marriage exists to create bonds between two families and to produce legitimate offspring. After her marriage, the wife maintained her nomen which was taken directly from her father. As such, within the new household hername remained an ever present reminder that she was not born into the familia, but married into it. ${ }^{155}$ We should also consider the nature of Roman marriage and its several legal forms. The most ancient of the practices, the conferratio, was a religious rite wherein the wife was directly under the control of the husband and divorce was impossible, though these marriages seem exceptionally rare and only practiced by patricians. The coemptio was a formal ceremony that could happen at any time of a marriage and included the formal 'purchasing' of a bride from her father. the practice of purchasing a bride is not uncommon in the world. The transactional

\footnotetext{
${ }^{154}$ A more cohesive collection of scholarly discussion on the question of Hostilia's age is in: Briscoe 2008503.

${ }^{155}$ Smith 200632.
} 
was ritualistic and conferred no actual ownership. Both of these institutions saw a transfer of the bride from one family to another. Though we should also consider the common practice of the trinoctem, wherein a wife would leave the house of her husband and stay on her father's property for three nights each year. By doing so, she prevented becoming under the control of her husband, and thus her father remained her pater familias. ${ }^{156}$ These types of marriage seemed to have been particularly common and thus reinforces the clear notion that matronae, married women, despite their idealisation as the pinnacle of womanhood, simultaneously outsiders in their own homes. Quarta Hostilia perhaps best embodies these conflicting interests in how she is prosecuted for killing her new husband to help her son from a previous marriage. Considering this, we see some correlation to studies of Zulu society where newly married women are statistically much more likely to be identified as witches, due to their perception by their new family and neighbours as an enemy within. Considering this, we can see that the position of matron and women in general, as one imbued with social tension and in this way she does conform with the belief of the witch as both insider and outsider and one who threatens the patriarchal norm, but to say that this is enough to resolutely claim that Livy's matron veneficae fulfil the social role of a witch as it is understood by anthropology.

On the whole it hard to resolutely claim that the veneficae that is seen in Livy was a witch, perhaps most damningly because they do not possess any malignant powers. A more convincing argument is that the venefica of literature was a witch in this sense. As we discussed in chapter one, the characters of Canidia and Erictho are perhaps two of the most famous witches of ancient Rome and certainly first this mould of witch. Horace's Canidia, violates taboo routinely. She lives in a graveyard, a place that is ritualistically unclean, polluted, and exists on the fringe of the city (Hor. Sat. $1.85-10$ ). She pilfers corpses for ingredients to use for magic, and murders indiscriminately when she requires fresh materials for her potions (Epo.

\footnotetext{
${ }^{156}$ The types of marriages in Rome are well discussed in: Treggiari 1993 17-28.
} 
5. 31-5). She is old, ugly, and inherently evil. Lucan's Erictho, though being written slightly later, has much in common with Canidia, she too lives in a graveyard and harvests corpses for eyes, fingernails, and other ingredients (Luc. 538-53). In addition to living on the fringe of society in a graveyard, she is more explicitly an outsider as she is a Thessaly, meaning she is an uncivilised foreigner. While we do not need to repeat what was already said in chapter one, considering these characters then we can say with some degree of certainty that an anthropological witch image existed in Rome, though they existed in popular culture and not in the annals of Livy.

In spite of our caution in declaring the veneficae as they are described in Livy to be witches, it is much more compelling to consider the quaestiones in Livy as witch hunts. Indeed, while a witch hunt takes its name from the historical witch hunts of the sixteenth and seventeenth centuries in Europe, a witch hunt is not entirely reliant on the presence of witches. In anthropology and sociology, it is an explosion of societal tensions which results in $\mathrm{n}$ the victimisation of a subject group. Witchcraft accusations are associated with tension and social conflict, and because social changes often generate interpersonal conflict and anxieties, we may expect periods of rapid and intensive change in societies to be characterised by a heightened concern of about witchcraft. This is certainly the case from anthropological field work in Africa. In these studies, labour migration saw young men leave ancestral homelands and the draining the village of its workforce and moving to other communities which increased competition for jobs in those areas. Christian missions were penetrating into the continent, spreading new ideas and practices while simultaneously displacing and destabilising indigenous religious ideas, including traditional beliefs about witchcraft and sorcery. ${ }^{157}$ Similar trends are apparent in most examples of anthropological fieldwork. ${ }^{158}$ Indeed this is also present in the European witch hunts. The Great Witch Craze of of the late Sixteenth and Seventeenth centuries AD. In this instance the witch hunt occurred during the tumultuous

\footnotetext{
${ }^{157}$ Gluckamn 1959 101-2.

${ }^{158}$ For summary of cases including Navaho, Shona, and Yoruba see: Sanders 1995 200-205.
} 
religious wars of the Reformation and Counter-Reformation. In these cases the dominant faith in a region equated witchcraft with devil-worship. ${ }^{159}$ Russell takes the argument further by arguing that the associated population migration caused by the religious wars contributed to the rise of witch accusations as disenfranchised foreigners moved into new communities. ${ }^{160}$ This is all to say that a witch hunt, is a release of built up social stress. These facets all combined to create an environment wherein society was changing at a rapid pace and witchcraft accusations evolved into witch hunts. As was discussed in chapter three, Rome was undergoing similar changes to its economic, social, and cultural institutions during the period that immediately preceded and during the veneficae hunts.

While considering who was prosecuted and why, we must inevitably consider the concept of 'scapegoating.' The term derives its name from the biblical book of Leviticus, when one goat is sacrificed for Jehovah in the hope for absolution, and another is released into the wilderness. The sacrificed goat bears sin, so the other can roam free. At its most simplistically it can be defined as the one or group who is blamed, punished or stigmatised, and in doing so, freeing themselves of hardship or disaster. A functionalist approach to scapegoat theory would argue the following: an external force, such as disease or disaster, threatens a social system. This results in a lack loss of solidarity and social unity. Society rejects those perceived as deviant and thus identifies them as an internal threat (i.e. the scapegoat), persecution of the social deviant re-established solidarity in the community as everyone by persecuting the deviant. ${ }^{161}$ In this model, scapegoating only occurs as a reaction to an external force. Furthermore, scapegoat theory also posits that the role of scapegoat, if empty, can be refilled by new deviants as needed until social solidarity is returned. ${ }^{162}$ It important here to differentiate persecution for scapegoating. Persecution involves the punishment of a person or group for crimes against the community, while scapegoating persecutes those deemed to be symbolic of

\footnotetext{
${ }^{159}$ Trevor-Rope 1988,64-7; 112-6.

${ }^{160}$ Russell 1981 82-5.

${ }^{161}$ A summary of this functionalist approach to Scapegoating can be found in: Lauderdale 1976663

${ }^{162}$ Erikson 1961314.
} 
of the threats against the community, much like the goats symbolised sin when sacrificed to Jehovah. Therefore the violence in scapegoat theories take the blame for problems as either an intentional diversionary tactic or as a cathartic explosion of anger and frustration. ${ }^{163}$ Scapegoat theory allows for transference of this mantle. This is to say, if society requires a scapegoat it can label any deviant or outsider as such. ${ }^{164}$ Thus if we consider this was present in the quaestiones of the second century then we can see several groups that more easily may have been labelled outsiders or deviants as veneficae.

We should also consider once again the status of Italians in Rome, in relation to the quaestiones. From Livy, we see that the number of people executed in the rural area outside of Rome greatly outnumbers the number of prosecutions inside of the city, this may have been explained by the marginalised status that these people possessed. The praetors investigating outside of Rome focused their searches firstly in municipia conciliabulaque (Liv. 39. 39. 41. 6) and then in in the fora conciliabulaque (Liv. 40.37. 4). The fora and concilibula were small rural communities founded by Rome. Fora were largely founded on major roadways, while the concilibula were more spontaneous in creation but also was founded and populated by Roman citizens. ${ }^{165}$ Municipia in the second century were larger communities that had been incorporated into the Roman order. These communities were largely self governing and their citizens in the second century were primarily cives sine suffragio, possessing only some of the rights of a roman citizen. ${ }^{166}$ These populations thus existed in the Roman mind as an ambiguous outsider that belonged to their own community and yet existed apart from it. As discussed in the previous chapter, during the period at the height of the conflict we see that Rome's relationship is already strained due to the economic depression following the Hannibalic war and the migration of Italians into Roman settlements where they lacked full rights. It is in this

\footnotetext{
163 Jensen 200653.

164 Jensen 200641.

${ }^{165}$ Knowledge of these communities' rights, organisation, and administration is sadly lacking due to the absence of material on them. Though the information provided here stems from: Sandys 1974 366 .

${ }^{166}$ Scullard 200116.
} 
context that we should also consider the quaestio of 184 which further outlines that, in addition to the quaestio tasked with investigations outside of Rome, that Tarentum was under the direct command of the praetor following its decision to rebel against Rome in the Hannibalic, there was banditry by disenfranchised farmers, and the Bacchinalia investigation was still ongoing and prosecuting people (Liv. 39. 41.5-7). In this context then we see that Italy, particularly in the south was in a state of crises. As discussed above, migration was believed to have caused outbreaks of witch accusations. Considering this we might assume that, in these Roman communities, the recent influx of southern Italians into Roman communities would have caused social pressure due the employment competition in an already depressed economy. The reputation for Italians in this period was poor due to their betrayal of Rome in the Hannibalic war, was compounded by the outbreak of banditry, in an inquisitional and ad hoc travelling quaestio these Italians may have been liable to be accused of veneficium.

We might also consider the sagae, or wise women, as victims of the quaestiones due to self- incrimination. There existed in Rome a tradition similar to that of cunning folk in the form of the sagax. Sagae should be translated as "wise women," phenomenon in Rome and Italy. Cicero speaks contemptuously of the "superstitions of wise women" (Div. 1.129.63). His disapproval appears to stem from the elite's more general disbelief that special knowledge or powers could be possessed by anyone but themselves. Cicero however does illuminate his reader whether these sagae were widespread or not. Indeed, we must turn to Columella for that evidence. In his De Re Rustica, Columella, warns estate managers to never allow wandering "Haruspices sagasque" onto the farm. The sagae, he warns, incite fear with false superstitions and force the managers into committing "shameful practices" for profit (Columella, Rust. 1.8. 5-6). The nature of this warning suggests several things. Firstly, like Cicero, Columella disapproves of these wandering sagae, and considers belief in their powers foolish. Secondly, that it was a relatively regular

\footnotetext{
${ }^{167}$ I have been convinced that this translation is the correct translation instead of the common "witch" by Ripat 2016 104-28.
} 
occurrence for elderly women claiming arcane knowledge to appear on farms, or at least common enough for Columella to believe it worthwhile in including in his agricultural treatise. Thirdly, considering both the first and second points, we must assume that clients and slaves responsible for the management of estates were regularly employing these people. This said it is not clear what shameful services were offered by the Haruspices sagasque. Though we can make some educated guesses from the evidence what these practices were. Pliny records references to the insecticidal powers of mensum piacula (petrifications of menstrual blood), though also notes that their toxicity was such that any direct contact between the blood and plant would cause it to immediately die (HN 28.70). This example perhaps provides an oblique clue of the kind of rituals that might have been performed by these sagax. ${ }^{168}$ When taken in concert with a fragment of Festus that provides a list of synonyms for female specialists (sacredos, simulatrix, saga, and expiatrix), we see he also noted that purgamenta ("filth") was synonymous with piamenta, the items that were involved with the ritualistic purification of polluted things. ${ }^{169}$ These things all considered, we thus see that there was a tradition in Italy of the travelling wise women who provided magical or homeopathic services to the many farming estates. In the eyes of the elite, these women were little more than con artists employing profane and foul superstitions. These women, considering their practices associated with the polluted may well have been the subject of accusation during the praetors' quaestiones and contributed to some of those swept up in the prosecutions.

The response in Rome to this social upheaval might best be called a 'Moral Panic,' a term often used by sociologist when discussing witch hunts. Stanley Cohen, who popularised the term "moral panic" observes, "Societies appear to be subject, every now and then, to

\footnotetext{
${ }^{168}$ Ripat 2016 117. Though Ripat fails to address the fact that, what few studies of menopause in the ancient world, poor nutrition and what was a hard life drastically hastened the onset of menopause in women. That said, these same features would, presumably, have also aged one prematurely.

${ }^{169}$ Lindsay 1913234.
} 
periods of moral panic. A condition, episode, person or group of persons emerges to become defined as a threat to societal values and interests." ${ }^{\prime 170}$ These moral panics begin with a small and localised event which is perceived and characterised as deviant. In turn, the event is sensationalised by the media, and the issue is then championed by authorities who provide solutions. ${ }^{171}$ The object of fear could be novel or traditional, but regardless becomes a "folk devil," in that it conforms to deviant antisocial stereotypes. ${ }^{172}$ While Cohen's work principally focussed on British society's response to Mod and Rocker subcultures in the 1960's, its broad nature means its application is widespread. Sociologists Erich Goode and Nachman BenYehuda suggest five criteria for the formation of a moral panic. These criteria are: concern, hostility, consensus, disproportionality, and volatility. Concern describes a heightened level of fear over a group's behaviour (or believed behaviour) and the potential consequences of this behaviour on the rest of society. Hostility describes the feeling that a respectable, law abiding society feels towards the perceived enemy that threatens its. Consensus describes the minimal measure of agreement within a society that the threat is real and requires action. Disproportionality describes how the society assumes that the threat is much greater than any empirical evidence would prove. Finally, volatility describes how moral panics can erupt, reach a fever pitch, then suddenly subside. ${ }^{173}$ These criteria can clearly be seen in the witch hunts described above and also in the quaestiones de veneficiis, were society fears and victimised a group that they believe is endangering it. As we have argued throughout, the venfica of Livy is not a witch, but in many ways she is an outsider and a threat to the Roman traditions and ingrained institutions. Considering this it is not surprising that they become the ideal scapegoat of Roman panic and focus of a witch hunt. ${ }^{174}$

\footnotetext{
${ }^{170}$ Cohen ( 3 ed.) 20021.

${ }^{171}$ Cohen (3 ed.) 20022.

${ }^{172}$ Cohen (3 ed.) 2002 4-5.

${ }^{173}$ Goode \& Ben-Yehuda 1994 156-159.

${ }^{174}$ Indeed, this characterisation of witch hunts would also mean that, despite the exclusion of the bacchic worshippers as witches, the quaestiones de bacchanalibus itself definitely fits the mould of a witch hunt. But also nearly all of the quaestio in this period can be seen to conform with this.
} 
This said, we also have sufficient evidence to posit the specific type of moral panic during the veneficae hunts. There are, generally speaking, three theories about why moral panics exist as a societal reaction. The Grassroots model argues that a panic originates with the general public, and that their outcry is so intense that their fear spreads to other parts of society and forces the government to take action. The Interest Group theory argues that specific groups launch moral crusades and intentionally stoke a moral panic to ensure that a group perceived as devious is removed. Finally, and most relevant to our cases, is the Elite engineered model. This model describes moral panics as the product of a small and powerful elite that is responsible for the deliberate generation and sustaining of a moral panic. ${ }^{175}$ This final model is undoubtedly the most relevant to this thesis and conforms with the evidence provided by Livy.

When considering the relationships between elites and panics there are three primary explanations that can be used: elites fearing panic, elites panicking, and elites creating panic. ${ }^{176}$ It is also possible to see multiple panic relationships acting simultaneously. Elites might fear panic because it results in a loss of control. When the public is concerned for their own wellbeing, they may no longer believe that elite are capable of providing protection. This panic challenges the very function of elite whose position is claimed due their ability to represent and improve the lives of their communities. This differs from elite's panicking in that it represents a more base, irrational panic focussed solely amongst the elite. This in turn, can creating a situation wherein the elites create panic. Elites creating panic is perhaps the most vital of these concepts for this thesis. Elites are so labelled because of their control of social apparatus, be it political or religious. Such control means that they are effectively able to communicate to the public that there is a cause for concern and they have the means to quash it. Because of their control, what is a local concern effecting a small majority of a given society is able to have far and long reaching effects. Considering these things, it is hard not to see both

\footnotetext{
${ }^{175}$ Goode \& Ben-Yehuda 1994 161-166.

${ }^{176}$ Clarke \& Chess 2008996.
} 
elites panicking and elites causing panic as the primary causes of the veneficium hunts found in Livy.

A panic emphasises an already established dichotomy within a social structure, and there are few greater divisions in any given society than that between the elite and the public. This division is starker in Republican Roman where the power over political and religious institutions was concentrated exclusively into several families. It is within this power structure that we should consider both prodigium and quaestio as institutions that simultaneously rationalised and facilitated elite control of society. From a functional and political perspective, both systems were a means of coping with crises. ${ }^{177}$ By focusing fears into an area which the ruling elite could claim a special inherited expertise; either because of the strict birth requirements inherent to some religious offices or the virtus, gloria and other aristocratic virtues considered prerequisite to holding the higher magistracies, ${ }^{178}$ while the remedia might offer an opportunity to hold elaborate ceremonies, and sometimes even new festivals, further boosting the city's morale with an impressive civic displays, or by highly public and inquisitorial trials. ${ }^{179}$ These displays therefore served not only to ease public panic but reminded the public of the elite power.

Additionally, we see examples of elite panic is more consequential than the panic of the masses. In our examples from 331 and 180 (Liv. 8.18.3; 40.37.1), it is explicitly stated that only when leading figures of the state died that foul play become suspected and an

\footnotetext{
${ }^{177}$ In times of sensational stress there was an increase in the reports of prodigies that suggest that the institution was employed most intensely when public anxiety was at a peak and reassurance was most needed. Helplessness created environments of fear and, in a society that believed its world was governed by supernatural forces, this tension took the form of a religious fear and only sated spectacular responses by the state. Perhaps the most famous of this was the rituals performed after the Roman defeat at Lake Trasimene in the second Punic war which saw the sacrifice of 300 oxen, games costing 333,333 asses, and religious processions requiring participation of all inhabitants of Rome (Liv. 21.9-10). While this stands as an extreme example, it does illustrate how in times of great societal concern there was an equally great state response.

${ }^{178}$ Earl 1967 22ff.

${ }^{179}$ For this point on prodigii see: Beard, North \& Price 1998 37-9.
} 
investigation was commissioned by the Senate. If the pestilence were contained among the lower classes, then it is unlikely that a quaestio would have taken place as the lower classes alone lacked the power to prosecute, convict, and execute the accused venefici. Using Elite Panic theory, we should pause and consider the quaestiones in years which did not include specific mention of elite deaths. In these instances, there are multiple possible potential reasons for their actions. First, there were in fact aristocratic deaths and Livy simply failed to record them. Second, the aristocratic classes were still fearful and sought to eradicate the perceived threat from the previous years. Thirdly, the aristocratic classes led quaestiones out of a perceived civic duty. All of these alternatives are plausible and fit within the construct of an elite panic.

An additional component that one might consider is that the quaestio, born of moral panic, became a manifestation of moral panic itself. Typically, Roman law was accusatorial, in that one person stood before a jury and accused another person of a crime. Failure to provide evidence resulted in the accuser being discredited. Indeed, trials for veneficium in the late Republic and empire are relatively standard legal proceedings that conformed to this mould. ${ }^{180}$ It is in these environments that we also have instances of people being found not guilty of veneficium. However, the quaestiones seen in Livy appear to have been born out of a perceived threat to the state and therefore were more aggressive and inquisitorial in nature. The quaestiones saw senior magistrates imbued with imperium leaving Rome, actively seeking out venefici, with ad hoc trials, gathering information through denunciation and informants. This methodology resulted in a staggering amount of condemnations and no recorded acquittals. ${ }^{181}$ Indeed, we should recall that in $179 \mathrm{BC}$ the praetor C. Maenius writes to the senate inform them that he has halted his investigation because at his current rate he will spend his entire praetorship investigating poisoning (40.43.3).

\footnotetext{
${ }^{180}$ Lintott 2003 157ff.

${ }^{181}$ Lintott 2003 96-7; 157
} 
The final component of moral panics is that as suddenly as they appear, they can also dissipate. Cohen explains that when society recognises that the the state has taken measures to resolve the cause of panic then the panic will end with surprising speed. After the influx of quaestiones between 191 and $179 \mathrm{BC}$, the last quaestio de veneficiis was in $154 \mathrm{BC}$, after which there was no large scale investigations into veneficium. While Livy's history from 167 to 91 $\mathrm{BC}$ is lost, we would assume, as was the case in $154 \mathrm{BC}$, that any of these cases would be included in the periochae. Their absence suggests that there were no addition outbreaks of veneficium hysteria in Rome and can by the establishment of quaestio perpetuo which specialised in prosecuting venfici at some point between 149 and 98 BC. ${ }^{182}$ This court system was finalised with the Lex Cornelia de Sicariis et Veneficiis passed in $81 \mathrm{BC}$ under L. Corneilus Sulla, by which he reorganised and augmented the system of standing courts that had been developed since the middle of the second century $\mathrm{BC}$ and combined the quaestio perpetuo tasked with investigating both sicarii (assassins) and venefici. This suggests that during the gap in our knowledge a significantly more codified means of reporting and prosecuting accused venefici had become established rendering the inquisitorial model moot and effecting the change in the community required to stop a moral panic into poisoning.

Having outlined how the large scale investigations into witch hunts were elite panics, let us consider the fullest account of veneficium hysteria in Rome in this model. Prior to the accusations of veneficium, disease had broken out. The similarities between disease and poison are note worthy and similarly effective on the community. A sudden and unexpected death damaged the social structure more drastically than a death from old age, or drawn out illness. In those instances, families and social institutions have the opportunity to prepare and ensure some degree of continuity. While unexpected deaths required that any damage done be repaired

\footnotetext{
182 The quaestio de repetundis, the court which dealt with the recovery of money illicitly obtained by Romans in positions of authority abroad, was established in 149 served as the model for the later established permanent quaestio. Lintott argues that this development was in 142, five years after the the quaestio de repetundis. In: Linott 2003, 158. Though this date is debated, Briscoe argues that regardless of this, the terminus ante quem was 98. In: Briscoe 2008345.
} 
as quickly and visibly as possibly. The rituals performed following the declaration of a prodigium fulfilled this societal role. Soothing fears and ensuring the community that things would return to normal and the natural way of things would be restored. Similarly, the deaths of the matrons in 331 performed this role too. What matters here, regardless of the story is true or not, is that that the Roman tradition. The trail and suicide of the matrons, by their own poisons no less, re-establishes the order of things, to the extent that it constituted the symbolic counterpart of veneficium aimed at the leading citizens. In this way we see a panic erupt due to disease, the state identifies the cause, it is removed and social order is restored.

With our anthropological and sociological models, we see a means by which we can interpret and understand the large scale veneficium investigations that we find in Livy. Using these models, we see that, while the veneficae of Livy were not witches in any anthropological sense, the claim that the quaestiones were witch hunts holds much more weight. While we cannot identify the veneficae as witches, we can see a way in which it was not merely roman matrons that were prosecuted in the veneficium investigations but also those that were deviants, claimed magical powers, or were simply social outsiders. These were most likely the true victims of these witch hunts. A witch hunt, in a sociological sense, explains any organised persecution of a group that society has deemed dangerous and whose prosecution is required. Witch hunts typically occur during a period of social anxiety and their suddenness and violence is a release of built up societal pressure, much as we explained in the previous chapter. When we consider the witch hunt further, we can also see how the quaestiones bear all the hallmarks of a moral panic, in particular an elite panic. 


\section{Conclusion}

The large scale investigations of Veneficium in the early history of Rome have been largely unexplored by scholarship and yet their study can reveal some fascinating truths about the nature of veneficium, the moralising tone of Livy, and how Roman society was prone to witch hunts in the second century.

Veneficium and its associated language can have a number of meanings, though attestations by modern scholars to the word's ambiguity are flawed. It is with this ambiguous definition that academia has typically approached the outbreaks of veneficium in Livy. In the standard lexica we see it equated with poisoning, the brewing of medicinal drugs, and magic. However, this methodology is fundamentally flawed as it fails to consider how the word developed.

When we consider how veneficium developed chronologically and in the different types of sources we can effectively track its evolution over time. By doing that we can assume that, in its earliest incarnation it was not that ambiguous at all. As we look at the language in our sources, we see a clear development from a word that referred to poisoning, that came to also mean making or administering medicine, and eventually magic more generally. This evolution was probably in large part due to Roman perceptions of the world that allowed for something to be both unknowable and uncanny without being supernatural. This was manipulated by rhetoricians in the first century $\mathrm{AD}$ to emphasise veneficium uncanny nature to assist their clients. In this way it became enforced by the jurists for whom we rely to understand the laws relating to veneficium. Later still this same fluidity facilitated its equation as the material substance that facilitated spells though required its pairing with an oral word to imply magic, eventually by the fourth century AD we see that, though the word was rarely used, by itself it could imply magic

Indeed, our analysis of the four large scale investigations of veneficium in Livylargely 
remain faithful to an older and traditional understanding of veneficium and its associated language. Veneficium here refers solely to poisoning, it refers to a material substance, and does not possess any magical meaning. Considering this then we have no reason to doubt that the quaestiones in Livy occurred, nor do we have any reason to doubt that the matrons specifically named in $331 \mathrm{BC}, 180 \mathrm{BC}$, and $154 \mathrm{BC}$ were prosecuted and executed upon having been found guilty of veneficium. Though we can also see in his text is influenced by the connotations of veneficium in his own time, such as the courtroom drama, the conflation of medicamentum with venenum, and association of fraus to emphasis its surreptitiousness. Livy's additional beliefs about Rome being in a state of moral decline also permeates his work and his discussion of the investigations of veneficium. It is through this lens that we can see posit why Livy might have chosen to emphasis these prevalent themes and motifs.

When considering the investigations into veneficium we cannot ignore that the majority of these quaestiones were clustered in a short period during a time when Rome and Italy were undergoing extensive changes to their social and political structures. These included the end of the Hannibalic War, which resulted in extensive urban migration and the end of the independent peasant farmer, the Hellenization of elite culture due to increased exposure to Greece and the East in the second century, and the continued deterioration of relations between Rome and the Italian allies that eventually resulted tin the Social Wars. This thesis posits that when we consider some of the accompanying motifs of venfecium, then we can see in the moralising Livy, the spate of quaestiones is one of several indicators that Rome was, from his perspective, in a state of moral decline. This suggests in turn that the quaestiones de veneficiis were in fact a violent reaction to socio-cultural changes in Rome during the second century. 
By engaging with anthropology and sociology we can see that our post hoc claim that economic and social change in Roman and Italy resulted in the large scale venefici hunts, has some theoretical support. While, we see the veneficae in Livy does wholly match with the witch in any strict anthropological sense, we can see how women, foreigners, and sagae might be labelled outsiders and become scapegoats in these trials. What is considerably more valuable to this thesis, however, is how the quaestiones bear some similarities to witch hunts. They occur during a period of social anxiety and their suddenness and violence is a release of built up societal pressure. The quaestiones described in Livy fit this model well. Indeed, we can see in them glimpses of scapegoating, as well as moral panic and elite panics.

It is in this light that we can see the quaestiones de veneficiis are not curiosities relegated to a few pages in a larger piece of scholarship but worthy of further study to illustrate that these were not merely violent inquisitions but in fact a normative social response to a rapidly changing social environment. 


\section{Appendix}

Appendix one

Foedus insequens annus seu intemperie caeli seu humana fraude fuit, M. Claudio Marcello Valerio consulibus. Flaccum Potitumque varie in annalibus cognomen consulis invenio; ceterum in eo parvi refert quid veri sit; illud pervelim — nec omnes auctores sunt—proditum falso esse, venenis absumptos quorum mors infamem annum pestilential fecerit; sicutproditur tamen res, ne cui auctorum fidem abrogaverim, exponenda est. Cum primores civitatis similibus morbis eodemque ferme omnes eventu morerentur, ancilla quaedam ad Q. Fabium Maximum aedilem curulem indicaturam se causam publicae pestis professa est, si ab eo fides sibi data esset haud futurum noxae indicium. Fabius confestim rem ad consules, consules ad senatum referunt, consensuque ordinis fides indici data. Tum patefactum muliebri fraude civitatem premi matronasque ea venena coquere, et si sequi extemplo velint, manifesto deprehendi posse. Secuti indicem et coquentes quasdam medicamenta et recondita alia invenerunt. Quibus in forum delatis et ad viginti matronis, apud quas deprehensa erant, per viatorem accitis, duae ex eis, Cornelia ac Sergia, patriciae utraque gentis, cum ea medicamenta salubria esse contenderent, ab confutante indice bibere iussae, ut se falsum commentam in conspectu omnium arguerent, spatio ad conloquendum sumpto, cum submoto populo rem ad ceteras rettulissent, haud abnuentibus et illis bibere, epoto medicamento suamet ipsae fraude omnes interierunt. Comprehensae extemplo earum comites magnum numerum matronarum indicaverunt; ex quibus ad centum septuaginta damnatae. Neque de veneficiis ante eam diem Romae quaesitum est. Prodigii ea res loco habita captisque magis mentibus quam consceleratis similis visa; itaque memoria ex annalibus repetita in secessionibus quondam plebis clavum ab dictatore fixum alienatasque discordia mentes hominum eo piaculo compotes sui fuisse, dictatorem clavi figendi causa creari placuit. Creatus Cn. Quinctilius magistrum equitum L. Valerium dixit, qui fixo clavo magistratu se abdicaverunt. (Liv. 8.18.1-13)

A terrible year succeeded, whether owing to the unseasonable weather or to man's depravity. The consuls were Marcus Claudius Marcellus and Gaius Valerius. I find Flaccus and Potitus severally given in the annals, as the surname of Valerius; but it does not greatly signify where the truth lies in regard to this. One thing, however, I should be glad to believe had been falsely handed down - and indeed not all the authorities avouch it — namely, that those whose deaths made the year notorious for pestilence were in reality destroyed by poison; still, I must set forth the story as it comes to us, that I may not deprive any writer of his credit. When the leading 
citizens were falling ill with the same kind of malady, which had, in almost every case the same fatal termination, a certain serving-woman came to Quintus Fabius Maximus, the curule aedile, and declared that she would reveal the cause of the general calamity, if he would give her a pledge that she should not suffer for her testimony. Fabius at once referred the matter to the consuls, and the consuls to the senate, and a pledge was given to the witness with the unanimous approval of that body. She then disclosed the fact that the City was afflicted by the criminal practices of the women; that they who prepared these poisons were matrons, whom, if they would instantly attend her, they might take in the very act. They followed the informer and found certain women brewing poisons, and other poisons stored away. These concoctions were brought into the Forum, and some twenty matrons, in whose houses they had been discovered, were summoned thither by an apparitor. Two of their number, Cornelia and Sergia, of patrician houses both, asserted that these drugs were salutary. On the informer giving them the lie, and bidding them drink and prove her charges false in the sight of all, they took time to confer, and after the crowd had been dismissed they referred the question to the rest, and finding that they, like themselves, would not refuse the draught, they all drank off the poison and perished by their own wicked practices. Their attendants being instantly arrested informed against a larg number of matrons, of whom one hundred and seventy were found guilty; yet until that day there had never been a trial for poisoning in Rome. Their act was regarded as a prodigy, and suggested madness rather than felonious intent. Accordingly, when a tradition was revived from the annals how formerly in secessions of the plebs 1 a nail had been driven by the dictator, and how men's minds, which had been distracted by dissension, had by virtue of that expiation regained their self-control, they resolved on the appointment of a dictator to drive the nail. The appointment went to Gnaeus Quinctilius, who named Lucius Valerius master of the horse. The nail was driven and they resigned their posts.

(8.18.1-13) (Ed. \& Tr). Foster. 1919 71-3. 


\section{Bibliography}

Bauman, R. A. 1974. 'Criminal Prosecutions by the Aediles.' Latomus. 33.2:245-64.

Baxter, P. T. W. 1972. 'Absence Makes the Heart Grow Fonder. Some Suggestions Why Witchcraft Accusations are Rare among East African Pastoralists.' in (ed.) M. Gluckman. The Allocation of Responsibility. Manchester. 163-91.

Beard, M., North, J., and Price, S. 1998. Religions in Rome. Volume I: A History. Cambridge.

Beard, M., and Crawford, M. 1985. Rome in the Late Republic. Bristol.

Briscoe, J. 2008. A Commentary on Livy: Books 38-40. Oxford.

Broughton, T. R. 1951. The Magistrates of the Roman Republic. Vol. 1. New York.

Brunt, P. A. 1971.Italian Manpower, 225 BC - AD 14. Oxford.

1998. The Fall of the Roman Republic. Oxford.

Burridge, K. M. 1965 'Tangu, Northern Madang District.' in: (eds.) P. Lawrence, and M. J. Meggitt. Gods, Ghosts and Men in Melanesia. Oxford. 224-49

Cloud, J. D. 1968 'How did Sulla style his Law de sicariis?' The Classical Review. 18:2 1403

Cohen, S. (3ed.) 2002. Folk Devils and Moral Panics. London and New York

Cornell, T. 1996. 'Hannibal's Legacy: The Effects of the Hannibalic War on Italy.' Bulletin of the Institute of Classical Studies. 67. 97-117

Clarke, L., and Chess, C. 2008 'Elites and Panic: More to Fear than Fear Itself,' Social Forces, 87:2. 993-1014.

Cloud, J. D. 1968. 'How did Sulla style his Law de sicariis?' The Classical Review. 18:2. 140-3.

Crawford, J. R. 1967. Witchcraft and Sorcery in Rhodesia. Oxford.

Cunningham, G. 1999. Religion and Magic. New York.

Dickey. E. 2002. Latin Forms of Address: From Plautus to Apuleius. Oxford.

Dickie, M. W. 2001. Magic and Magicians in the Greco-Roman World. London.

Earl, D. 1967. The Moral and Political Tradition of Rome. London.

Edwards, C. 1993. The Politics of Immorality in Ancient Rome. Cambridge.

Erikson, K. T. 1961 'Notes on the Sociology of Deviance.' Social Problem. 9:1. 307-14.

Evans-Pritchard, E. 1937. Witchcraft, Oracles and Magic among the Azande. Oxford. 
Ferrary, J. L. 1991. 'Lex Cornelia de sicariis et veneficis.' Athenaeum. 79: 417-34.

Gargola, D. J. 2017. The Shape of Roman Order. Chapel Hill.

Garnsey, P. 1988. Famine and Food Supply in the Graeco-Roman World. Cambridge.

Gluckamn, M. 1959. Custom and Conflict in Africa. Oxford

1965. Politics, Law and Ritual in Tribal Society. Oxford.

Gelford, M. 1967. The African Witch. Edinburgh and London.

Graf, F. Magic in the Ancient World. (tr.) F. Philip. Cambridge, Mass. 1997.

Goode, E., and Ben-Yehuda, N. 1994. 'MORAL PANIC: Culture, Politics, and Social Construction' Annual Review of Sociology. 20. 149-71.

Gordon, R. 1999. 'Imagining Greek and Roman Magic.' (eds.) Flint, V., Gordon, R., Luck, G., Ogden, D. Witchcraft and Magic in Europe, Volume 2 Ancient Greece and Rome. London.

Herman, J. 2000. Vulgar Latin. University Park, Penn.

Hoffman, C. A. 2002. 'The Idea of Magic in Roman Law.' Dissertation. Berkley.

Holmes. C. 1993. 'Women, Witnesses and Witches.' Past and Present. 140. 45-78

Jackson, R. 1988. Doctors and Disease in the Roman Empire. Norman and London.

Jensen, G. 2006. The Path of the Devil: Early Modern Witch Hunts. Lanham.

Kaufman, D. B. 1932 'Poisons and Poisoning among the Romans.' Classical Philology. 27.2: 156-67.

Keaveney, 1987. A. Rome and the Unification of Italy. London.

Kosak, J. C. 2000. 'Polis Nosousa: Greek ideas about the city and disease in the fifth century BC.' in: (eds.) Hope, M. and Marshall, E. Death and Disease in the Ancient City. London and New York. 35-54.

Kudlien, F. 1970. 'Medical Ethics and Popular Ethics in Greece and Rome,' Clio Medica. 91121.

Lauderdale, P. 1976. 'Deviance and Moral Boundaries.' American Sociological Review. 41.4: 660-76.

Larner, C. 1985. Witchcraft and Religion. The Politics of Popular Belief. Oxford.

Lee-Stecum, P. 2006. 'Dangerous Reputations: Charioteers and Magic in Fourth-Century

Rome.' Greece \& Rome. 53. 2: 224-234. 
Levene, D. S. 1993. Religion in Livy. Lieden

Liebeshuetz, J. H. W. G. 1979. Continuity and Change in Roman Religion. Oxford.

Lewis, I. M. 1986. Religion in Context. Cults and Charisma. Cambridge.

Lintott, A. W. 1999. The Constitution of the Roman Republic. Oxford.

1972. 'Imperial Expansion and Moral Decline in the Roman Empire,'

Historia. 21.4: 626-38

Lambek, M. 1993. Knowledge and Practice in Mayotte: Local Discourses of Islam Sorcery, and Spirit Possession. Toronto.

Lindsay, L. The Latin Language. Oxford. 1894.

Lindsay, W. M. (Tr.) 1913. Sexti Pompei Festi: De Verborum Significatu Quae Supersunt cum Pauli Epitome. Leipzig.

Livy. 1919. (Ed. \& Tr.) B. O. Foster. History of Rome. volume VIII. Cambridge, MA.

Livy. 1919. (Ed. \& Tr.) B. O. Foster. History of Rome. volume IV. Cambridge, MA.

Macfarlane, A. 1970. Witchcraft in Tudor and Stuart England. A Regional and Comparative Study. London.

Mair, L. 1969. Witchcraft. London.

Mankin, D. 1995. Horace’s Epodes. Cambridge.

Manning, C. E. 1970. 'Canidia in the Epodes of Horace.' Mnemosyne. 23. 4: 393-401.

Mommsen, T. 1899. Römisches Strafrecht. Graz.

North, J. A. 1986. 'Religion and Politics, from Republic to Principate.' Journal of Roman Studies. 76: 1-8.

Nutton, V. 2000 'Medical Thoughts on Urban Pollution.' in: V. M. Hope \& E. Marshall (eds.), Death and Disease in the Ancient City. London and New York. 65-84.

2004. Ancient Medicine. London and New York.

Oakley, S. P. 1998. A Commentary on Livy Books VI-X. Oxford.

Oliensis, E. 1991. 'Canidia, Canicula, and the Decorum of Horace's 'Epodes,' Arethusa, 24.1:107-38.

1998. Horace and the Rhetoric of Authority. Cambridge. 
Orlin, E. 2010. Foreign Cults in Rome: Creating a Roman Empire. Oxford.

Paule M. T. 2014. 'QVAE SAGA, QVIS MAGVS: On the Vocabulary of the Roman Witch.' The Classical Quarterly. 64.2: 745-757.

Paule, M. T. 2017. Canidia, Rome’s First Witch. London and New York.

Pharr, C. 1932. 'The Interdiction of Magic in Roman Law.' Transactions of the American Philological Society. 63: 269-95

Phillips, C.A. 1991. 'Nullum Crimen sine Lege: Socioreligious Sanctions on Magic.' in: C.A. Faraone and D. Obbink (eds.). Magika Hiera: Ancient Greek Magic and Religion. 260-270.

Pinkster, H. 1990. Latin Syntax and Semantics. Oxford.

Quintilian. 2006. (ed. \& tr.) D. R. Shackleton Bailey. The Lesser Declamations. Cambridge, MA.

Rives, J. B. 'Magic in Roman Law: The Reconstruction of a Crime.' Classical Antiquity. 22.2: $313-339$

Rives, J. B. 2002. 'Magic in the XII Tables Revisited.' The Classical Quarterly, 52.1: 270-90

Rosenberger, V. 2007. 'Republican Nobiles: Controlling the Res Publica. in: J. Rüpke, (ed.). A Companion to Roman Religion. Oxford. 292-303

Rüpke, J. 2007. Companion to Roman Religion. Oxford.

Ripat. P. 2016. 'Roman Women, Wise Women, and Witches.' Phoenix. 70.1: 104-28

Sanders, A. 1995. A Deed Without Name: The Witch in Society and History. Oxford and Washington DC.

Sandys, J. E. 1974. A Companion to Latin Studies. Cambridge.

Scullard, H. H. (5ed.) 2001. From the Gracchi to Nero. New York.

Smethurst, S. E. 1950. 'Women in Livy's History.' Greece \& Rome, 19.56: 80-87

Smith, C. J. 2006. The Roman Clan. Cambridge.

Smith, M.1978. Jesus the Magician. San Francisco.

Sussman, L. 1994.The Declamations of Calperinus Flaccus. Leiden.

Stewart, P. J. \& Strathern, A. 2004. Witchcraft, Sorcery, Rumours, and Gossip. Cambridge.

Talbert, R. J. A. 1984. The Senate of Imperial Rome. Princeton. 
Thomas, K. 1973. Religion and the Decline of Magi. London.

Toynbee, A. J. 1965. Hannibal's Legacy. vol. 2. Oxford.

Treggiari, S. 1993. Roman Marriage. Oxford.

Trevor-Rope, H. R. 1988. The European Witch-Craze of the Sixteenth and Seventeenth Centuries. London.

Versnel, H. 1991. 'Some Reflections on the Relationship Magic-Religion.' Numen. 38.2: $177-97$

Watson, A. (ed.). 1998 The Digest of Justinian. Vol.1. Philadelphia. 